\title{
Optimization of Production and Partial Characterization of Keratinase Produced by Bacillus thuringiensis strain Bt407 Isolated from Poultry Soil
}

\author{
Victoria Uttangi and K. Aruna* \\ Department of Microbiology, Wilson College, Mumbai-400 007, India \\ *Corresponding author
}

\begin{tabular}{|l|}
\hline Ke y w o r d s \\
Bacillus \\
thuringiensis strain \\
Bt407, Keratinase, \\
Zymography \\
\hline Article Info \\
\hline $\begin{array}{l}\text { Accepted: } \\
\text { 07 March } 2018 \\
\text { Available Online: } \\
10 \text { April } 2018\end{array}$ \\
\hline
\end{tabular}

\section{Introduction}

Keratin forms a major structural component of
vertebrate skin (epidermis) and its appendages
viz. hair, feathers, nails, horns, hoofs, scales
and wool (Feughelman, 1985). It is used in
hair care products, animal feed and fibres for

Keratin forms a major structural component of
vertebrate skin (epidermis) and its appendages
viz. hair, feathers, nails, horns, hoofs, scales
and wool (Feughelman, 1985). It is used in
hair care products, animal feed and fibres for

Keratin forms a major structural component of
vertebrate skin (epidermis) and its appendages
viz. hair, feathers, nails, horns, hoofs, scales
and wool (Feughelman, 1985). It is used in
hair care products, animal feed and fibres for

Keratin forms a major structural component of
vertebrate skin (epidermis) and its appendages
viz. hair, feathers, nails, horns, hoofs, scales
and wool (Feughelman, 1985). It is used in
hair care products, animal feed and fibres for

Keratin forms a major structural component of
vertebrate skin (epidermis) and its appendages
viz. hair, feathers, nails, horns, hoofs, scales
and wool (Feughelman, 1985). It is used in
hair care products, animal feed and fibres for

\section{A B S T R A C T}

Microbial keratinases have become biotechnologically important since they target the hydrolysis of highly rigid, strongly cross-linked structural polypeptide "keratin" recalcitrant to the commonly known proteolytic enzymes. Soil samples collected from different poultry shops were enriched for keratinase producers on Whole feather agar containing whole feathers as a sole Carbon and Nitrogen source. Among 11 bacterial isolates, 6 isolates showed protease activity. The best keratinase producing bacterium K10 was selected and identified as Bacillus thuringiensis strain Bt407, based on morphological, cultural, biochemical characteristics and 16S rRNA sequence analysis. The isolate exhibited maximum keratinase production $(94.52 \mathrm{U} / \mathrm{ml})$ in a optimized feather meal medium containing Feather meal (2\%), Yeast extract (1\%), Starch (1\%), $\mathrm{MgSO}_{4} 6 \mathrm{H}_{2} \mathrm{O}$ (0.003\%), $\mathrm{CaCl}_{2}(0.5 \mathrm{mM}), \mathrm{KH}_{2} \mathrm{PO}_{4}(0.5 \%), \mathrm{K}_{2} \mathrm{HPO}_{4}(0.3 \%), \mathrm{NaCl}(0.5 \%), \mathrm{pH} 7$, inoculated with $1 \% \mathrm{v} / \mathrm{v}$ pre-grown cell mass and incubated at $37^{\circ} \mathrm{C}$ on rotary shaker $(120$ $\mathrm{rpm}$ ) for 48 hours. The optimum enzyme activity was observed at $55^{\circ} \mathrm{C}$ and $\mathrm{pH} 8$. Metal ions like $\mathrm{Ca}^{+2}, \mathrm{Mg}^{+2}$ and $\mathrm{Ba}^{+2}$ were seen to enhance enzyme activity whereas $\mathrm{Cd}^{+2}, \mathrm{Cu}^{+2}$, $\mathrm{Fe}^{+3}, \mathrm{Hg}^{+2}$ and $\mathrm{Zn}^{+2}$ were observed to inhibit enzyme activity. Inhibitors such as SDS helped to retain the activity of the enzyme while 2- mercaptoethanol, DMSO and EDTA were seen to inhibit the enzyme activity. The molecular weight of the keratinase was found to be $33 \mathrm{kDa}$ by SDS-PAGE method. Zymography was carried out to show protease activity of the keratinase. Depilatory action of keratinase on goat skin was also demonstrated. The applications of the enzyme as a detergent additive and enzyme hydrolyzed feather meal in bacteriological medium as nitrogen source were also studied. Of the tested keratinous materials used as substrates, the production of enzyme was seen to be more in the presence of human nails than human hairs. textiles (Mitsuiki et al., 2004). Keratin is an insoluble fibrous protein macromolecule with very high stability and low degradation rate. On the basis of secondary structural conformation, keratins have been grouped into $\alpha$ ( $\alpha$-helix of hair and wool) and $\beta$ ( $\beta$-sheets of feather) (Voet and Voet, 1995; Akhtar and Edwards, 1997). Keratins are also classified as 
Type I (acidic) keratin and Type II (basic) keratin and have molecular weights ranging from $30 \mathrm{KDa}$ to $70 \mathrm{KDa}$ (Steinert, 1993; Selvam and Vishnupriya, 2012). There are approximately 30 different types of keratins which are generally grouped into epithelial keratins (in epithelia cells) and trichocytic keratins which make up hair, nails, horns and reptilian scale.

Keratins are also classified as soft keratins and hard keratins (Zhou et al., 1988; Chou et al., 2015). Soft keratins (those containing up to 1 $\%$ sulphur) which constitute less amount of disulfide bonds are commonly present in skin and callus structure (epithelial keratin) and are more pliable. Hard keratins which are tough (those containing up to $5 \%$ sulphur), constitute large amount of disulfide bond and exist in form of $\alpha$ keratin and $\beta$ keratin (trichocytic keratin) (Voet and Voet, 1995; Schrooyen et al., 2001).

The most distinctive feature of keratin is, they are mechanically robust and chemically unreactive (high resistance to proteolytic degradation) due to presence of higher degree of cross-linking by disulphide bridges, salt bridges, hydrogen bonds and hydrophobic interactions. Keratin is poorly susceptible to degradation and digestion by most common peptidases such as trypsin, pepsin and papin (Bockel et al., 1995; Balaji et al., 2008; Jones et al., 1997).

Keratinase [E.C.3.4.21/24/99.11] are proteases able to degrade the scleroprotein keratin. Keratinases belong to group of proteolytic enzymes which have ability to hydrolyze insoluble protein keratin more efficiently than other proteases (Onifade et al., 1998). Due to the strength and stability of keratin, very few microorganisms are able to degrade keratin and utilize it as carbon, nitrogen and sulphur source (Marchisio, 2000). Total degradation of keratinous material by specialized microorganisms can generate a chain of events involving breaking of disulfide bridges (sulfitolysis) and proteolysis (Błyskal, 2009; Ramnani et al., 2005). It is due to the cooperative action of keratinolytic protease and disulfide reductase enzyme which may be produced by same or different microorganisms (Gupta et al., 2015).

Microbial keratinases are mostly extracellular enzymes which are inducible in nature but some are membrane linked (cell bound) and intracellular. Keratinases are by and large serine or metalloproteases which are capable of degrading the structural keratinous protein (Gupta and Ramnani, 2006). Keratinase are also classified into two major groups "endopeptidases and exoproteases" based on their site of cleavage action. These enzymes are produced by bacteria, actinomycetes and fungi which can hydrolyze a large number of keratin substrates (Saibabu et al., 2013; Tork et al., 2010). Bacterial keratinases are also capable of degrading other proteins like casein, collagen and gelatin (Balakumar et al., 2013).

There are reports of isolating keratinase producing microorganisms from poultry soil, poultry wastes, poultry farm, poultry processing industry, feather and hair dumping sites and barbers' landfill (Deivasigamani and Alagappan, 2008; Gioppo et al., 2009; Sahoo et al., 2015; Syed et al., 2009; Kaul and Sumbali, 1997; Moallaei et al., 2006; Xu et al., 2009; Manoj Kumar et al., 2016; Shah, 2015).

A major proportion of feather degrading bacteria belong to Gram positive category of Bacillus spp. which includes Bacillus licheniformis, Bacillus amyloliquefaceins, Brevibacillus brevis US575, Bacillus tequilensis strain Q7, Bacillus pumilus, Bacillus cereus, Bacillus subtilis and Bacillus halodurans (Jaouadi et al., 2013; Jaouadi et 
al., 2015; Lin et al., 1992; Cortezi et al., 2008; Kumar et al., 2010; Adiguzel et al., 2009; Mazotto et al., 2010; Prakash et al., 2010). Other Gram positive feather degrading bacteria include Micrococcus spp., Nesterenkonia sp. AL20, Arthrobacter creatinolyticus KP015744, Caldicoprobacter algeriensis, Kytococcus sedentarius, Micrococcus luteus, and Clostridium spp, (Ionata et al., 2008; Kate and Pethe, 2014; Bakhtiar et al., 2005; Longshaw et al., 2002; Laba et al., 2015). Keratinolytic gram negative bacteria belong to Pseudomonas spp., Vibrio spp., Chryseobacterium spp., Xanthomonas spp., Lysobacter NCIMB 9497, Acinetobacter sp. PD 12, Stenotrophomonas and Fervidobacterium spp. (Allpress et al., 2002; Sangali and Brandelli, 2000, De Toni et al., 2002, Yamamura et al., 2002, Lucas et al., 2003; Shah, 2015; Cao et al., 2009). Actinomyces species such as Streptomyces flavis 2BG (mesophilic) and Microbispora aerata IMBAS-11A (thermophilic), Nocardiopsis dassonvillei NRC2aza (Gushterova et al., 2005; Azza, 2013) can also degrade keratin. Keratinases are also produced by fungi including Paecilomyces marquandii, Myrothecium verrucaria, Aspergillus flavus Strain K-03, Cladosporium and Trichoderma, Cyberlindnera fabianii Nrc3, Purpureocillium lilacinum LPS \# 876, Chrysosporium georgiae, Doratomyces microspores, Onygena corvine and Candida parapsilosis (Veselá and Friedrich, 2009; Gioppo et al., 2009; Kim, 2007; Patience et al., 2015; Naghy et al., 1998; Friedrich and Kern, 2003; Huang et al., 2015; Duarte et al., 2011).

The current studies focuses on isolation and identification of keratinase producing isolate obtained from soil around the poultry shops. It further discusses the optimization of keratinase production. It also reports partial purification, characterization and applications of keratinase enzyme.

Materials and Methods

\section{Collection of samples}

The soil samples were collected from the vicinity of the locations of four poultry shops in Mumbai city in the clean dry plastic containers

\section{Enrichment}

One gm of soil sample was mixed with $10 \mathrm{ml}$ of Distilled water. The mixture was shaken well and allowed to settle for $30 \mathrm{~min}$. Five $\mathrm{ml}$ of soil supernatant was inoculated in $95 \mathrm{ml}$ of Whole feather basal medium in flask. This medium was prepared using Whole feathers $(20 \mathrm{~g} / \mathrm{L})$ that were incorporated in Feather Basal broth Medium which is composed of $\mathrm{NaCl} \quad(0.5 \mathrm{~g} / \mathrm{L},) \quad \mathrm{K}_{2} \mathrm{HPO}_{4}(0.3 \mathrm{~g} / \mathrm{L}), \mathrm{KH}_{2} \mathrm{PO}_{4}$ (0.4g/L), pH 7.4 (Tork et al., 2010). The flasks were incubated at $37^{\circ} \mathrm{C}$ in shaker condition $(120 \mathrm{rpm})$ till visible degradation or disappearance of the feathers (Agrahari and Wadhwa, 2010).

\section{Isolation}

Feather-meal agar plates were prepared by adding $\mathrm{NaCl}(0.5 \mathrm{~g} / \mathrm{L}), \quad \mathrm{K}_{2} \mathrm{HPO}_{4} \quad(0.3 \mathrm{~g} / \mathrm{L})$, $\mathrm{KH}_{2} \mathrm{PO}_{4}(0.4 \mathrm{~g} / \mathrm{L})$, Agar $(20 \mathrm{~g} / \mathrm{L})$ and Feather meal $(20 \mathrm{~g} / \mathrm{L})$, which was used as a sole source of carbon and nitrogen. Its $\mathrm{pH}$ was adjusted to 7.4 (Selvam and Vishnupriya, 2012).

The feather meal was prepared from native chicken feathers which were cut with scissors into small pieces of 3 to $4 \mathrm{~cm}$ long and washed several times with tap water. Defatting of feather pieces was done by soaking them in a mixture of chloroform: methanol (1:1) for 2 days followed by chloroform: acetone: methanol (4:1:3) for 2 days. The solvent was replaced every day. The feathers were finally washed several times with tap water to eliminate the solvent residual, dried for $24 \mathrm{hrs}$ in an oven at $50^{\circ} \mathrm{C}$ and grinded using electrical 
mixer blender (Kenstar Senator PCMG 0120) and used as feather meal (Saibabu et al., 2013; Riffel and Brandelli, 2006). The enriched suspension was streaked on feather meal agar plates and plates were incubated at $37^{\circ} \mathrm{C}$ for 72hrs. Single colonies were isolated and screened for their ability to produce protease by using Skimmed Milk Agar plates (Riffel $e t$ al., 2003; Tork et al., 2010). The cultures were spot-inoculated on Skimmed Milk Agar plates and incubated at $37^{\circ} \mathrm{C}$ for $24-48 \mathrm{hrs}$. The colonies showing a zone of clearance of $>11 \mathrm{~mm}$ around the colony was considered to have a proteolytic activity and hence Keratinolytic activity (Riffel and Brandelli, 2006).

\section{Keratinase assay}

\section{Preparation of crude enzyme extract}

Cultures were grown on sterile feather meal broth medium on shaker incubator (120 rpm) at $37^{\circ} \mathrm{C}$ for $24 \mathrm{hrs}$. The broth was centrifuged at $3000 \mathrm{rpm}$ for $20 \mathrm{mins}$. The cell pellet was washed and resuspended in phosphate buffer saline $\mathrm{pH}$ 7.2. Washed cells $(5 \mathrm{ml})$ are then inoculated in $100 \mathrm{ml}$ of Feather meal basal medium and incubated for $24 \mathrm{hrs}, 48 \mathrm{hrs}$ and $72 \mathrm{hrs}$ at $37^{\circ} \mathrm{C}$ on shaker incubator (120rpm). After incubation an aliquot of the broth is centrifuged and the supernatant containing the enzyme extract was assayed by Keratin azure assay. The protein content was estimated by Folin- Lowry method (Lowry et al., 1951).

\section{Keratinase azure assay}

This assay was carried out by using the modified method of. Bressollier et al., (1999). Keratin azure (Sigma Aldrich, Germany Sigma) was used as a substrate. One $\mathrm{ml}$ of crude enzyme extract was incubated with $5 \mathrm{mg}$ of keratin azure in $1 \mathrm{ml}$ of $50 \mathrm{mM}$ Tris $\mathrm{HCl}$ buffer $(\mathrm{pH} 8.5)$ at $50^{\circ} \mathrm{C}$ for $1 \mathrm{hr}$ with constant agitation at $100 \mathrm{rpm}$. The mixture was centrifuged at $3000 \mathrm{rpm}$ for $20 \mathrm{mins}$ to remove the insoluble substrate. The supernatant was measured spectrophotometrically (UVVisible Spectrophotometer- Agilent Technologies Cary 60 UV- vis) at $595 \mathrm{~nm}$ for the release of the azo dye. All assays were done in triplicate. One unit (U) of keratinase was defined as the amount of enzyme causing 0.01 increase in absorbance between sample and control at $595 \mathrm{~nm}$ after one hour under the conditions given. The culture showing good proteolytic activity was selected and studied for their best keratinase producing ability in the shortest period of time (Letourneau et al., 1998; Sangali and Brandelli., 2000; Cortezi et al., 2008; Anbu et al., 2005; Suntornsuk et al., 2005).

\section{Protein estimation}

Protein concentration of the supernatant was determined by using the Folin-Lowry Ciocalteau method. Bovine serum albumin was used as a standard and the colour developed was read at $660 \mathrm{~nm}$ (Lowry et al., 1951)

\section{Identification}

Identification was carried out on the basis of morphological, cultural and biochemical properties using Bergey's Manual of Bacteriology $8^{\text {th }}$ Edition (1974). Further confirmation of the strain was done by $16 \mathrm{~s}$ rRNA sequencing analysis (Codon Biosciences Pvt. Limited, Goa).

\section{Media optimization for keratinase production}

Sterile feather meal basal medium $100 \mathrm{ml}$ was inoculated with $5 \mathrm{ml}$ culture suspension of the isolate $(0.1$ O.D. at $530 \mathrm{~nm})$ and were incubated in shaker incubator at $37^{\circ} \mathrm{C}$ for 48hrs. Static condition was maintained as control. The $100 \mathrm{ml}$ of sterile feather meal 
basal production medium was prepared in different flasks and inoculated with 5\% inoculum. To check effect of temperature each flask was incubated at different temperature such as $28^{\circ} \mathrm{C}, 37^{\circ} \mathrm{C}, 45^{\circ} \mathrm{C}$ and $55^{\circ} \mathrm{C}$ for 48 hours. To study the effect of $\mathrm{pH}$ each flask of $100 \mathrm{ml}$ medium adjusted to different $\mathrm{pH}$ such as 5, 6, 7, 8, 9 and 10 using $1 \mathrm{~N} \mathrm{NaOH}$ and 1 $\mathrm{N} \mathrm{HCl}$. To demonstrate the effect of carbon source each flask was added with $1 \%$ of different carbon sources such as Glucose, Lactose, Maltose, Xylose, Mannitol, Glycerol and Starch.

To investigate the effect of nitrogen source each flask was added with $1 \%$ different sources of nitrogen such as Urea, Yeast extract, Peptone, and Tryptone. To observe the effect of salt concentration each flask was added with different concentrations of $\mathrm{MgSO}_{4}$ $6 \mathrm{H}_{2} \mathrm{O}(0.5 \mathrm{mg}, 1 \mathrm{mg}, 3 \mathrm{mg}, 5 \mathrm{mg})$ and different concentrations of $\mathrm{CaCl}_{2} \quad(0.5 \mathrm{mM}, 1 \mathrm{mM}$, $1.5 \mathrm{mM}$ and $2 \mathrm{mM}$ ).

A final enzyme assay was done after the isolate was grown in the optimized medium with components such as $\mathrm{NaCl} 0.05 \%$, $\mathrm{KH}_{2} \mathrm{PO}_{4} 0.07 \%, \mathrm{~K}_{2} \mathrm{HPO}_{4} 0.14 \%$, starch $1 \%$, yeast extract $1 \%, \mathrm{CaCl}_{2} 0.5 \mathrm{mM}, \mathrm{MgSO}_{4} 6 \mathrm{H}_{2} \mathrm{O}$ $0.003 \%$, feather meal $1 \%, \mathrm{pH} 7$ at $37^{\circ} \mathrm{C}$ on shaker conditions(120 rpm) for $48 \mathrm{hrs}$.

\section{Partial purification of Keratinase enzyme}

The crude extract fluids $(200 \mathrm{ml})$ were precipitated by $80 \%$ saturation using ammonium sulphate. The addition of salt was done with constant stirring on a magnetic stirrer in an ice bath. The protein precipitate obtained was separated by centrifugation at $10,000 \mathrm{rpm}$ for $10 \mathrm{~min}$ and the pellet was dissolved with minimum volume of Tris- $\mathrm{HCl}$ buffer $\mathrm{pH}$ 8. The dissolved sample was dialyzed (Cellophane membrane, Sigma) against Tris- $\mathrm{HCl}$ buffer $\mathrm{pH} 8$ for $8 \mathrm{~h}$. The dialyzed enzyme was collected and assayed for its enzyme and protein activity. The specific activity and \% yield was calculated
(Lakshmi, 2013; Mukhopadhyay and Chandra, 1990; Mehta et al., 2014).

Effect of different parameters on the activity of keratinase

\section{Effect of pH on enzyme activity}

To determine the effect of $\mathrm{pH}$, enzyme assay (Keratin azure assay) was performed by preincubating $0.2 \mathrm{ml}$ of partially purified enzyme with $0.8 \mathrm{ml}$ of different $\mathrm{pH}$ buffers (Phosphate Buffer $\mathrm{pH}$ 7, Tris- $\mathrm{HCl} \mathrm{pH} 8$, Glycine- $\mathrm{NaOH} \mathrm{pH} 9$ and 10 ) at $30^{\circ} \mathrm{C}$ (Tatineni et al., 2008).

\section{Effect of temperature on enzyme activity}

To determine the effect of temperatures on keratinase activity $1 \mathrm{ml}$ of enzyme with $1 \mathrm{ml}$ of Tris- $\mathrm{HCl}$ buffer $\mathrm{pH} 8$ was incubated for $1 \mathrm{hr}$ at different temperatures such as $28^{\circ} \mathrm{C}, 37^{\circ} \mathrm{C}$, $55^{\circ} \mathrm{C}, 65^{\circ} \mathrm{C}, 75^{\circ} \mathrm{C}, 80^{\circ} \mathrm{C}$ and $85^{\circ} \mathrm{C}$. Later Keratin azure assay was carried out (Tatineni et al., 2008).

\section{Effect of metal ions on enzyme activity}

To determine the effect of divalent cations on keratinase activity the purified fraction of enzyme was preincubated in the presence of Zinc, magnesium, copper, calcium, mercury, cadmium and barium $\left(\mathrm{Zn}^{+2}, \mathrm{Mg}^{+2}, \mathrm{Cu}^{+2}, \mathrm{Ca}^{+2}\right.$, $\mathrm{Cd}^{+2}, \mathrm{Fe}^{+3}$ and $\mathrm{Ba}^{+2}$ ) chloride form at $2 \mathrm{mM}$ concentration for $15 \mathrm{mins}$ at $30^{\circ} \mathrm{C}$. Later Keratin azure assay was carried out (Kainoor and Naik, 2010; Suntornsuk et al., 2005).

\section{Effect of inhibitors on enzyme activity}

To determine the effect of different inhibitors on enzyme acitivity $1 \mathrm{ml}$ of enzyme was preincubated with $1 \mathrm{ml}$ of $5 \mathrm{mM}$ inhibitor solutions (EDTA, SDS, 2-Mercaptoethanol, DMSO)) for 15 mins at $30^{\circ} \mathrm{C}$. Later Keratin azure assay was carried out (Kainoor and Naik, 2010; Suntornsuk, 2005). 


\section{Determination of molecular weight}

In order to determine the molecular weight of this partially purified enzyme Sodium dodecyl sulfate (SDS)-polyacrylamide gel electrophoresis (PAGE) was carried out. SDSPAGE was performed with $12 \%$ polyacrylamide gels as described by (Laemmli, 1970). Molecular weight markers (molecular weights, 14,000 to 170,000 ; Boehringer, Mannheim, Germany) were included and stained with $1 \%$ Coomasie brilliant blue R-250 and then destained.

\section{Zymography}

To prepare a zymogram, proteinase samples were mixed with electrophoresis sample buffer without heat denaturation prior to electrophoresis. SDS-PAGE was carried out at $4^{\circ} \mathrm{C}$ by using a $12 \%$ polyacrylamide gel. After electrophoresis, the gel was washed with $2.5 \%$ (vol/vol) Triton X-100 for $30 \mathrm{~min}$ and then with $50 \mathrm{mM}$ Tris- $\mathrm{HCl}(\mathrm{pH}$ 8) for $30 \mathrm{~min}$. Casein $(2 \%, \mathrm{wt} / \mathrm{vol})$ in $50 \mathrm{mM}$ Tris-HCl buffer $(\mathrm{pH}$ 8.5) was then poured onto the gel slab containing proteases. After $1 \mathrm{hr}$ of incubation at $50^{\circ} \mathrm{C}$, the gel was stained with Coomassie brilliant blue R-250 prepared in solvent containing methanol: acetic acid: water (40:10:50) and then destained. Protease bands appeared as clear zones on a blue background (Bressollier et al., 1999).

Similarly after electrophoresis, the gel was soaked in $1 \%(\mathrm{w} / \mathrm{v})$ Triton-X-100 for $15 \mathrm{~min}$ and then in glycine-NaOH buffer (pH 10) for $30 \mathrm{~min}$ at $50^{\circ} \mathrm{C}$. The gel was now over layered on $1.2 \%$ agarose plate containing $0.5 \%$ casein in $50 \mathrm{mM}$ glycine- $\mathrm{NaOH}$ buffer $(\mathrm{pH}-8.5)$ for $1 \mathrm{hr}$ at $50^{\circ} \mathrm{C}$ and stained to visualize hydrolysed clear band. Hydrolysis of casein was observed on plate surrounding the gel slab (Kainoor and Naik, 2010; Jaouadi et al., 2013).

\section{Keratinase production using hair and nail as substrates}

Five ml culture suspension of $20 \mathrm{hrs}$ old log phase washed culture (0.10.D. at 530nm) was inoculated in sterile $100 \mathrm{ml}$ basal mineral medium containing $1 \%$ human hairs / nails and were incubated at $37^{\circ} \mathrm{C}$ for 7 days. Keratin azure assay was carried out at $24 \mathrm{hrs}$, 48hrs, 96hrs, $120 \mathrm{hrs}$ and $144 \mathrm{hrs}, 168 \mathrm{hrs}$ (Suntornsuk et al., 2005).

\section{Application of keratinase}

\section{Keratinase treated feather meal as bacteriological media additive}

Keratinase enzyme is a feather degrading enzyme which produces peptides and soluble proteins (amino acids) as the degradation products. These degradation products can be used as source of carbon and nitrogen in bacteriological media for growth of laboratory cultures (Ramakrishnan et al., 2011).

Media were used as follows

Sterile Nutrient Agar

Sterile medium with $1 \%$ degraded feather meal+ $0.5 \% \mathrm{NaCl}+2.5 \%$ Agar, $\mathrm{pH} 7.2$

Sterile plates with medium containing $0.5 \% \mathrm{NaCl}+2.5 \%$ Agar and $\mathrm{pH}$ 7.2.

The isolate was grown in sterile whole Feather basal medium and incubated at $37^{\circ} \mathrm{C}$ for 48 hrs. The grown medium was centrifuged at $5000 \mathrm{rpm}$ for $20 \mathrm{mins}$ and the precipitate was obtained. The precipitate was washed with sterile distilled water and it was autoclaved and incorporated in the medium as stated above. The laboratory cultures ( $24 \mathrm{hrs}$ old log phase culture of Escherichia coli, Staphylococcus aureus, Bacillus subtilis, Salmonella paratyphi B, Proteus vulgaris and 
Pseudomonas areuginosa were spot inoculated on them and sterile media controls were also maintained. All these plates were incubated at $37^{\circ} \mathrm{C}$ for 48 hrs. Growth was checked after incubation.

\section{Keratinase enzyme as detergent additive (Wash performance)}

Wash performance analysis of cotton cloth with blood and egg yolk stains was conducted and efficacy of the Keratinase for use as detergent additive was assessed (Pathak and Deshmukh, 2012; Adinarayana et al., 2003). Application of keratinase enzyme produced by the isolate as a detergent additive was studied on white cotton cloth pieces $(4 \times 4 \mathrm{~cm})$ stained with human blood and egg yolk. $7 \mathrm{mg} / \mathrm{ml}$ of Ariel detergent powder solutions were prepared. These were heated in boiling water bath for $20 \mathrm{~min}$ to inactivate the inherent enzymes. The following sets were prepared and studied.

Flask with distilled water $(100 \mathrm{ml})+$ stained cloth (cloth stained with blood / egg yolk).

Flask with distilled water $(100 \mathrm{ml})+$ stained cloth (cloth stained with blood / egg yolk) +1 $\mathrm{ml}$ heat inactivated ariel detergent $(7 \mathrm{mg} / \mathrm{ml})$.

Flask with distilled water $(100 \mathrm{ml})+$ stained cloth (cloth stained with blood / egg yolk) +1 $\mathrm{ml}$ heat inactivated ariel detergent $(7 \mathrm{mg} / \mathrm{ml})+$ $2 \mathrm{ml}$ of enzyme solution.

The piece of cloth was rinsed in above flasks for 30 minutes.

After incubation, cloth pieces were taken out, rinsed with water and dried.

Visual examination of various pieces exhibited the effect of enzyme in removal of stains. Untreated cloth pieces stained with blood / egg yolk were taken as control.

\section{Dehairing capacity of keratinase on goat skin}

Freshly salted goat hide was cut into pieces of approximately $2 \times 2 \mathrm{~cm}$ and washed with distilled water repeatedly to remove salt and extraneous matter. After brief air drying, the hide was weighed (weight of the pieces was maintained $3 \mathrm{~g}$ and transferred to a flask containing $10-\mathrm{ml}$ sterile distilled water (Macedo et al., 2005). The soaked hide pieces were incubated with the enzyme $(1 \% \mathrm{w} / \mathrm{v})$ at $37^{\circ} \mathrm{C}$ along with control which was goat hide of the same size with saline instead of enzyme (Pillai and Archana, 2008; Gurav et al., 2016). Incubations were carried out for 18 hrs after which hair was scraped off gently from the hides.

\section{Results and Discussion}

Sample collection, enrichment, isolation and identification

A screening program was employed to obtain bacterial isolates capable of producing feather degrading extracellular keratinase enzyme using feather (keratin) as sole carbon and nitrogen source. Four soil samples from different poultry shops from Mumbai were successfully enriched in Whole feather broth medium. The enriched broth culture from soil sample number 1 was used for all further experimentation as turbidity of the medium and degradation of the feathers appeared to be more. The enriched sample was streaked on feather meal basal medium agar and 11 isolates $\mathrm{K} 1, \mathrm{~K} 2, \mathrm{~K} 3, \mathrm{~K} 5, \mathrm{~K} 6, \mathrm{~K} 7, \mathrm{~K} 8, \mathrm{~K}$, $\mathrm{K} 10, \mathrm{~K} 11$ and K12 were obtained. All the 11 isolates were checked for their protease activity using Skimmed milk agar plates. Only 5 bacterial isolates number $\mathrm{K} 1, \mathrm{~K} 5, \mathrm{~K} 6, \mathrm{~K} 10$ and K12 showed larger zones of clearance i.e. protease activity around the colony on Skimmed milk agar plates (results not shown). This suggested that these isolates might 
possess keratinase activity as well. The above 5 isolates were grown on whole feather basal broth for $24 \mathrm{hrs}, 48 \mathrm{hrs}$ and $72 \mathrm{hrs}$. The capability of these isolates to produce maximum keratinase in the shortest period of time was studied. Out of 5 bacterial isolates, the isolate $\mathrm{K} 10$ was found to be the best producer of keratinase in $48 \mathrm{hrs}$ as shown in the figure 1 and 2. A significant reduction in enzyme production was observed in $72 \mathrm{hrs}$, thereby proving that the isolates produced maximum enzyme in the log phase. The whole feather basal medium was completely turbid, suggesting disintegration and degradation of the feathers in the medium. Protein concentration was estimated by employing Folin-Lowry method. K10 showed specific activity of 11.96 after $48 \mathrm{hrs}$ which was the highest among the specific activities of all the five isolates (Table 1). The isolate K10 which was showing maximum keratinase activity was identified as Bacillus thuringiensis strain Bt407 by morphological, cultural, biochemical and $16 \mathrm{~S}$ rRNA sequence analysis. It is grampositive, sporulating Bacillus which is soildwelling bacterium, commonly used as a biological pesticide. B. thuringiensis also occurs naturally in the gut of caterpillars of various types of moths and butterflies, as well on leaf surfaces, aquatic environments, animal faeces, insect rich environments, flour mills and grain storage facilities.

There are reports of isolating keratinase producing microorganisms from poultry soil, poultry wastes, poultry farm, poultry processing industry, feather and hair dumping sites and barbers' landfill (Deivasigamani and Alagappan, 2008; Gioppo et al., 2009; Sahoo et al., 2015; Syed et al., 2009; Kaul and Sumbali, 1997; Moallaei et al., 2006; Xu et al., 2009; Manoj Kumar et al., 2016; Shah, 2015). Similar Keratinase producing bacterial strains of Bacillus thuringiensis were also isolated from the chicken feather dumping site (Sivakumar et al., 2012; Shanker et al., 2014).
The presence of keratinous substrates usually induces keratinase production (Mazotto et al., 2010). In our studies enrichment and isolation of keratinase producer was carried out by using medium containing Whole feather as a sole carbon and nitrogen source which had induced higher keratinase activity (Lin et al., 1992; Szabo et al., 2000; Gushterva et al., 2005). Feather meal was used for isolation of keratinase producer by many scientists (Tapia and Simoes,2008; Ramya et al., 2014; Mousavi et al., 2013; Govarthanan et al., 2011; Shah, 2015; Fakhfakh-Zouari et al., 2010). The abilities of bacterial isolates to produce keratinase were also confirmed in earlier reports by cultivation on agar plates containing skimmed milk (Tork et al., 2010; Allpress et al., 2002; Preethi et al., 2015; Ramya et al., 2014; Kazi et al., 2015). Several Bacillus sp. including Bacillus licheniformis, Bacillus amyloliquefaceins, Brevibacillus brevis US575, Bacillus pumilus, Bacillus cereus, Bacillus subtilis, Bacillus halodurans have been documented to be potential sources of keratinases (Jaouadi et al., 2013; Lin et al., 1992; Cortezi et al., 2008; Kumar et al., 2010; Adiguzel et al., 2009; Mazotto et al., 2010; Prakash et al., 2010). There are other documentary evidences of keratinase production by other bacterial species like Bacillus subtilis, Bacillus coagulans, Bacillus cereus and Bacillus pumilus (Femi-Ola et al., 2015), Bacillus polymyxa and Bacillus cereus (Laba and Rodziewicz, 2010), Bacillus megaterium (Saibabu et al., 2013), Bacillus megaterium RS1(Shankar et al., 2013), Bacillus pseudofirmus FA30-01(Kojima et al.,2006), Brevibacillus thermoruber T1E(Bihari et al.,2010), Bacillus safensis LAU 13(Lateefa et al., 2015), Bacillus mycoides, Bacillus cereus, Bacillus vallismortis, Bacillus mojavensis (Preethi et al., 2015), Bacillus weihenstephanensis PKD5 (Sahoo et al., 2015), Bacillus pumilus AR57, Kocuria rosea (Bernal et al., 2006). Besides these, vast diversity also exists among other 
bacterial sources with keratinases being described from Fervidobacterium, Lysobacter, Nocardiopsis, Microbacterium (Thys et al., 2004), Clostridium sporogenes (Ionata et al., 2008), Chryseobacterium (Nam et al., 2002; Allpress et al., 2002; Mitsuiki et al., 2004; Silveira et al., 2010), Nocardiopsis dassonvillei NRC2aza (Azza, 2013), Stenotrophomonas (Cao et al., 2009), Chryseobacterium sp. (Brandelli and Riffel, 2005), Vibrio sp. kr2. (Grazziotin et al., 2006), Paecilomyces marquandii (Veselá and Friedrich, 2009), Myrothecium verrucaria (Gioppo et al., 2009), Aspergillus flavus Strain K-03 (Kim, 2007), Cladosporium and Trichoderma (Patience et al., 2015), Lysobacter NCIMB 9497 (Allpress et al., 2002), Vibrio (Sangali and Brandelli, 2000), Cyberlindnera fabianii Nrc3 (Azza, 2015), Nesterenkonia sp. AL20 (Bakhtiar et al., 2005), Purpureocillium lilacinum LPS \# 876 (Ivana et al.,2013), Penicillium spp. Morsy1 (El-Gendy, 2009), Onygena corvina (Huang et al., 2015), Acinetobacter sp. PD 12 (Shah, 2015), Arthrobacter creatinolyticus KP015744 (Kate and Pethe, 2014), Chrysosporium georgiae (El-Naghy et al., 1998), Doratomyces microspores (Friedrich and Kern, 2003), Streptomyces flavis 2BG (mesophilic) and Microbispora aerata IMBAS-11A (thermophilic)(Gushterova et al., 2005), Serratia sp. HPC 1383 (Khardenavis et al., 2009), Micrococcus luteus (Laba et al., 2015), Kytococcus sedentarius (Longshaw et al., 2002), Cunninghamella echinulata (More, 2013), Malbranchea gypsea (Singh, 1999) and Candida parapsilosis (Vermelho et al., 2009).

\section{Effect of various co-carbon sources on keratinase production}

Though all sugars were seen to support the production of Keratinase in case of Bacillus thuringiensis strain Bt407 grown in Feather Basal Medium with 1\% Starch showed the highest production of enzyme $(87.37 \mathrm{U} / \mathrm{ml})$ and degradation of feathers, followed by media containing Xylose, Glycerol and Glucose (Fig. 3). Enzyme production and feather degradation in medium containing $1 \%$ Maltose, Mannitol or Lactose showed scanty feather degradation and consequently exhibited low levels of keratinase production. Our results are in accordance with the reports where Bacillus sp strains (MBF11 and MBF21), Bacillus sp. JB 99, Bacillus megaterium RS1, Streptomyces gulbargensis DAS 131 and Streptomyces minutiscleroticus DNA38, B.cereus TS1 showed maximum keratinase production in presence of starch (Laxmi et al., 2013; Kainoor and Naik, 2010; Shankar et al., 2013; Allure et al., 2015; Sivakumar et al., 2013; Syed et al., 2009). However, in earlier studies Bacillus thuringiensis TS2 strain (Sivakumar et al., 2012) showed maximum keratinase production in presence of mannitol and minimum in presence of lactose whereas in case of B.cereus KER17, Chryseobacterium sp. RBT and Streptomyces exfoliatus CFS1068 starch has shown negative impact on feather degradation process (Gurav et al., 2016; Rayudu et al., 2011; Jain et al., 2012).

Previous studies also showed that in case of Bacillus licheniformis RG1 (Ramnani and Gupta, 2004), Bacillus subtilis MTCC9102 (Kumar et al., 2010), B. megaterium F7-1 (Park and Son, 2009), Bacillus Subtilis Subsp Subtilis (Manju and Shanmugam, 2013), Bacillus halodurans strain PPKS-2 (Pathange et al.,2009), Bacillus subtilis (MTCC9102) (Kumar et al., 2010), Streptomyces sp., Stenotrophomonas sp., (Yamamura et al.,2002; Jeong et al., 2010), Microbacterium and many fungal species (Kazi et al., 2013) glucose does have positive effect on Keratinase production. There are previous reports where Bacillus subtilis strain RM-01, Myrothecium verrucaria and B.subtilis S8 produced maximum keratinase in presence of maltose $(10 \%, w / w)$, bagasse and Sorbitol as best co-carbon source respectively (Rai et al., 2009; Gioppo et al., 2009; Jeong et al., 
2010a). Nevertheless, carbohydrate inhibition of keratinase production was observed in certain strains of bacteria (Brandelli and Riffle, 2005; Givskov et al., 1991; Wang and Shih, 1999; Thys et al., 2004; Yamamura et al., 2002a; Bernal et al., 2003; Gassesse et al., 2003; Suntornsuk and Suntornsuk, 2003; Kainoor and Naik, 2010; Daroit et al., 2011; Lo et al., 2012; Sahoo et al., 2015; Mabrouk, 2008).

\section{Effect of various co- nitrogen sources on the production of keratinase}

Bacillus thuringiensis strain Bt407 was inoculated into Feather Basal medium containing $1 \%$ Yeast extract showed the highest production of enzyme and degradation of feathers, $(79.26 \mathrm{U} / \mathrm{ml})$ followed by media containing $1 \%$ Urea. Growth media containing $1 \%$ Tryptone or Peptone as the nitrogen source did not show feather degradation to the degree seen in media containing the other nitrogenous compounds (Fig. 4). Similar results were showed by Bacillus subtilis AMR (Mazotto et al., 2010), Bacillus sp. JB 99 (Kainoor and Naik, 2010), B.licheniformis KMBVP (Vidhya and Palaniswamy, 2013), Bacillus polymyxa B20 and Bacillus cereus B5esz (Łaba and Rodziewicz, 2010) and Streptomyces minutiscleroticus DNA38 (Allure et al., 2015). However, Bacillus thuringiensis TS2 strain reported to produce maximum keratinase in presence of peptone and minimum in presence of ammonium nitrate (Sivakumar et al., 2012) whereas Bacillus subtilis (MTCC9102) demonstrated maximum keratinase production in presence of peptone (Kumar et al., 2010). But earlier studies reported that B.pumilus FH9, $B$. megaterium F7 and Stenotrophomonas maltophilia R13 exhibited maximum keratinase production in presence of yeast extract + ammonium chloride, Tryptone and $0.12 \%$ polypeptone respectively (El-Refai et al., 2005; Park and Son 2009; Jeong et al.,
2010). Chryseobacterium sp. RBT suppressed the keratinase activity in presence of inorganic and/or organic nitrogen sources (Gurav et al., 2016).

\section{Effect of incubation period on the production of keratinase}

Maximum keratinase production was observed at 48 hours after inoculation of the isolate Bacillus thuringiensis strain Bt407 in Feather meal basal medium (Figure 2). Similar results were obtained for Bacillus subtilis NCIM 2724 (Harde et al., 2011), B.subtilis MTCC 9102 (Kumar et al., 2010), Bacillus pumilus FH9 (El-Refai et al., 2005), B. cereus LAU08 (Lateef et al., 2010) and Stenotrophomonas maltophila R-13 (Jeong et al., 2010a). However, Bacillus thuringiensis TS2 was reported to produce optimum keratinase after $96 \mathrm{hrs}$ of incubation (Sivakumar et al., 2012) and Bacillus thurengenesis SN2 produced optimum keratinase in 5 days (Agrahari and Wadhwa, 2010). A decrease in the production of the enzyme after $48 \mathrm{hrs}$ of incubation can be due to the inactivation of the enzyme by metabolic end products accumulated in the medium or due to the depletion of nutrients in the medium (Anbu et al., 2005) There were studies where optimum keratinase was produced by Bacillus sp. JB 99 and Microbacterium after $36 \mathrm{hrs}$ (Kainoor and Naik, 2010; Thys et al., 2004). Jeong et al., (2010) reported Bacillus sp. SH-517 produce optimum keratinase after 40hrs whereas Bacillus sp. FK 28, Bacillus pseudofirmus, Xanthomonas maltophila POA-1 and Arthrobacter creatinolyticus KP015744 demonstrated maximum yield of enzyme in 72hrs (Pissuwan and Suntornsuk, 2001; Kate and Pethe, 2014; De Toni et al., 2002; Kojima et al., 2006). Optimum period of 5 days for keratinase production for B.megaterium F7-1 (Park and Son, 2007), Bacillus sp. FK46 (Suntornsuk and Suntornsuk, 2003), Streptomyces gulbargensis (Syed et al., 2009) 
and Bacillus licheniformis KMBVP (Vidhya and Palaniswamy, 2013) was also reported. Bacillus subtilis Subsp Subtilis and Brevibacillus thermoruber T1E with incubation of 7 days reported to give maximum enzyme yield (Manju and Shanmugam, 2013; Bihari et al., 2010) whereas 8 days was reported for Bacillus subtilis AMR (Mazotto et al., 2010).

Effect of various concentrations on Magnesium salt and calcium salt on the production of keratinase

Maximum keratinase production was observed in Feather Basal medium supplemented with $3 \mathrm{mg}$ of $\mathrm{MgSO}_{4} 6 \mathrm{H}_{2} \mathrm{O} / 100 \mathrm{ml}$ of medium by the isolate Bacillus thuringiensis strain Bt407. When inoculated in media containing $\mathrm{MgSO}_{4}$ $6 \mathrm{H}_{2} \mathrm{O}$ in concentrations greater than or lesser than $3 \mathrm{mg} / 100 \mathrm{ml}$, a reduction in synthesis of the keratinase by Bacillus thuringiensis strain Bt407 was observed (Fig. 5). Bacillus thuringiensis strain Bt407, when grown in Feather Basal medium containing $0.5 \mathrm{mM}$ $\mathrm{CaCl}_{2} 2 \mathrm{H}_{2} \mathrm{O}$, was found to induce higher enzyme production. A higher concentration of $\mathrm{CaCl}_{2}$ of $1 \mathrm{mM}$ or $2 \mathrm{mM}$ was seen to repress the production of keratinase (Fig. 6). In earlier studies the basic medium used for fermentation of the feather-degrading microorganisms such as Bacillus subtilis RSE163 (Gupta and Singh, 2013), Bacillus sp. JB 99 (Kainoor and Naik, 2008), Bacillus halodurans Strain PPKS-2 (Pathange et al., 2009), S. albidus E4 and S. griseoaurantiacus E5 (Kansoh et al., 2009) and Trichophyton sp. HA-2 (Anbu et al., 2008) contained $\mathrm{MgSO}_{4}$. The protease production is slightly stimulated by $\mathrm{CaCl}_{2}$ and $\mathrm{MgCl}_{2}$ and strongly inhibited by $\mathrm{CuSO}_{4}$. It was reported that the maximum keratinase production by Bacillus subtilis KD-N2 was obtained when the initial concentrations of $\mathrm{MgSO}_{4}$ was $0.91 \mathrm{~g} / \mathrm{L}$ (Cai and Zheng, 2009) whereas Streptomyces gulbargensis DAS 131 produced keratinase in a medium containing $\mathrm{CaCl}_{2}-0.2 \%$ and $\mathrm{MgSO}_{4}$ $7 \mathrm{H}_{2} \mathrm{O}-0.2 \%$ (Syed et al., 2009). Previous studies showed that basal medium containing

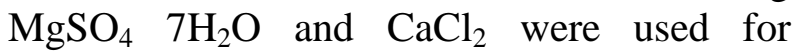
keratinase production in case of Bacillus subtilis (Pillai and Archana, 2008), Bacillus sp.SCB-3 (Lee et al., 2002), Bacillus megaterium (Saibabu et al., 2013), Bacillus pumilus FH9 keratinolytic (El-Refai et al.,2005), Bacillus subtilis MTCC 9102 (Balaji et al., 2008), Streptomyces sp: (Ramakrishnan et al., 2011), Bacillus cereus Wu2 (Lo et al., 2012), Pseudomonas aeruginosa C11 (Han et al.,2012), Aspergillus oryzae NRRL-447 (Ali et al., 2011), Actinomyces sp (Jayalakshmi et al.,2010) and Scopulariopsis brevicaulis (Anbu et al., 2007).

\section{Effect of pH and incubation temperature on the production of keratinase}

The medium was adjusted to different $\mathrm{pH}$ values such as $\mathrm{pH} \mathrm{5,} \mathrm{6,} \mathrm{7,} \mathrm{8,} 9$ and 10 and was assayed to obtain the optimum $\mathrm{pH}$ for the maximum production of keratinase by Bacillus thuringiensis strain Bt407. The maximum keratinase production was observed at $\mathrm{pH} 7$ as shown in figure 7. Different temperatures such as $28^{\circ} \mathrm{C}, 37^{\circ} \mathrm{C}, 45^{\circ} \mathrm{C}$ and $55^{\circ} \mathrm{C}$ were tested to obtain the optimum temperature for the maximum production of keratinase by Bacillus thuringiensis strain Bt407.The temperature at which the production of keratinase was maximum was observed to be $37^{\circ} \mathrm{C}$ (Fig. 8). However, maximum keratinase for Bacillus thuringiensis TS2 was observed at $\mathrm{pH} 10.0$ and $50^{\circ} \mathrm{C}$ (Sivakumar et al., 2012) and Bacillus thurengenesis SN2 showed optimum enzyme production at $30^{\circ} \mathrm{C}$ and $\mathrm{pH} 7.5$ (Agrahari and Wadhwa, 2010). Previous studies showed that maximum keratinase production by various bacterial species exhibited at different temperatures and $\mathrm{pH}$ values such as for Bacillus cereus TS1 was at $\mathrm{pH} 9$ and temperature $50^{\circ} \mathrm{C}$ (Sivakumar et al., 2013), 
Bacillus pumilus ZED17 at pH 10 and $37^{\circ} \mathrm{C}$ (Talebi et al., 2013), B. licheniformis KMBVP strain at $40^{\circ} \mathrm{C}$ and $\mathrm{pH} 8$ (Vidhya and Palaniswamy, 20130), Bacillus amyloliquefaciens at $\mathrm{pH} 8$ and $50^{\circ} \mathrm{C}$ (Cortezi et al., 2008), Bacillus subtilis strain RM-01 at $50^{\circ} \mathrm{C}$ and $\mathrm{pH} 8$ (Rai et al., 2009), Bacillus sp. JB 99 at $45^{\circ} \mathrm{C}$ and $\mathrm{pH} 10$ (Kainoor and Naik, 2010), Bacillus sp. MBRL 575 at $30^{\circ} \mathrm{C}$ and pH 9-10 (Ningthoujam and Kshetri, 2016), Brevibacillus thermoruber $\mathrm{T} 1 \mathrm{E}$ at $50^{\circ} \mathrm{C}$ and $\mathrm{pH} \quad 6.5$ (Bihari et al., 2010), Stenotrophomonas maltophilia at $30^{\circ} \mathrm{C}$ and 7.0 (Jeong et al., 2010), Lysobacter sp. A03 at temperature of $20^{\circ} \mathrm{C}$ and $\mathrm{pH} 7$ (Pereira et al., 2014), Streptomyces minutiscleroticus DNA38 at $45^{\circ} \mathrm{C}$ and $\mathrm{pH} 9$ (Allure et al., 2015) and Bacillus subtilis at $\mathrm{pH} 11$ and $40^{\circ} \mathrm{C}$ (Mousavi et al., 2013). Proteolytic activities of most organisms are seen to be $30-37^{\circ} \mathrm{C}$, whereas some Keratinolytic bacteria show feather degrading capacities at higher temperature (Riffel and Brandelli, 2006).

\section{Effect of static and shaker conditions on the production of keratinase}

Bacillus thuringiensis strain Bt407 showed a higher enzyme activity when incubated under agitation on a shaker at $120 \mathrm{rpm}$ as compared to incubation in a static condition (Fig. 9). Similar results were obtained for Bacillus thuringiensis TS2 (Sivakumar et al., 2012), Bacillus thurengenesis SN2 (Agrahari and Wadhwa, 2010) and Bacillus licheniformis PWD1 (Lin et al., 1996). Aeration is required for many bacterial species such as Bacillus sp. FK28 (150rpm), Bacillus licheniformis RG1 (250 rpm), Bacillus halodurans PPKS-2 (180rpm), Bacillus sp. P7 (130rpm) Vibrio sp. Kr2 (180rpm), Chryseobacterium sp. kr6 (180rpm), B.pumilus FH-9 (200 rpm), B.megaterium F7-1(200 rpm), Streptomyces exfoliatus CFS1068 (150 rpm) and Stenotrophomonas maltophila R-13 (200 rpm)
(Pissuwan and Suntornsuk, 2001; Ramnani and Gupta, 2004; Sangali and Brandelli, 2000; Riffel et al., 2003; Jeong et al., 2010b; Park and Son, 2007; El-Refai et al., 2005; Jain et al., 2012; Pathange et al., 2009; Correa et al., 2009) for maximum keratinase production. However, Thermoanaerobacter keratinophilus sp. nov. (Rissen and Antranikian, 2001), Fervidobacterium islandicum AW-1 (Nam et al., 2002) and Fervidobacterium pennavorans (Friedrich and Antranikian, 1996) reported to require static condition for maximum yield of keratinase.

Bacillus thuringiensis strain Bt407 exhibited a much higher enzyme activity (94.52Units/ml) when grown in optimized medium in comparison to the Whole feather basal medium (49.75Units/ml) which was used initially for the production of keratinase. In our studies optimized medium doubled the yield of enzyme.

Keratinase production using human hairs and nails

A steady increase in the keratinase enzyme production by Bacillus thuringiensis strain Bt407 in optimized medium containing human nails and human hairs was observed till 144hrs and after which there was decline in enzyme production (Fig. 10). Human nails were degraded efficiently than human hairs by the isolate. Similar results were obtained for Bacillus pumilis $\mathrm{F} 3-4, B$. megaterium $\mathrm{F} 7-1, B$. cereus TS1, B. licheniformis FK 14, Bacillus $\mathrm{sp}$, Bacilus licheniformis PWD-1, Microbacterium sp., Scopulariopsis brevicaulis, Streptomyces gulbargensis DAS 131 and Chryseobacterium sp. RBT strain (Peddu et al., 2009; Son et al., 2008; Park and Son, 2007; Gurav et al., 2016; Sivakumar et al., 2013; Thys et al., 2004; Cheng et al., 1995; Sharaf and Khalil, 2011; Syed et al., 2009). 
Fig.1 Different isolates showing degradation of feathers

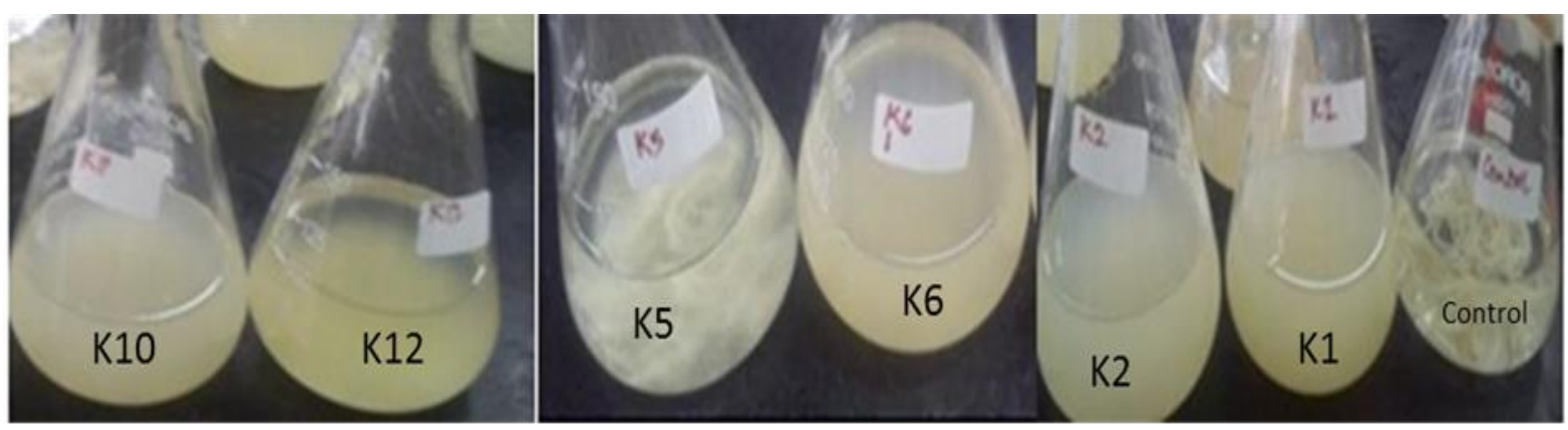

Fig.2 Keratinase assay of different isolates at various incubation periods

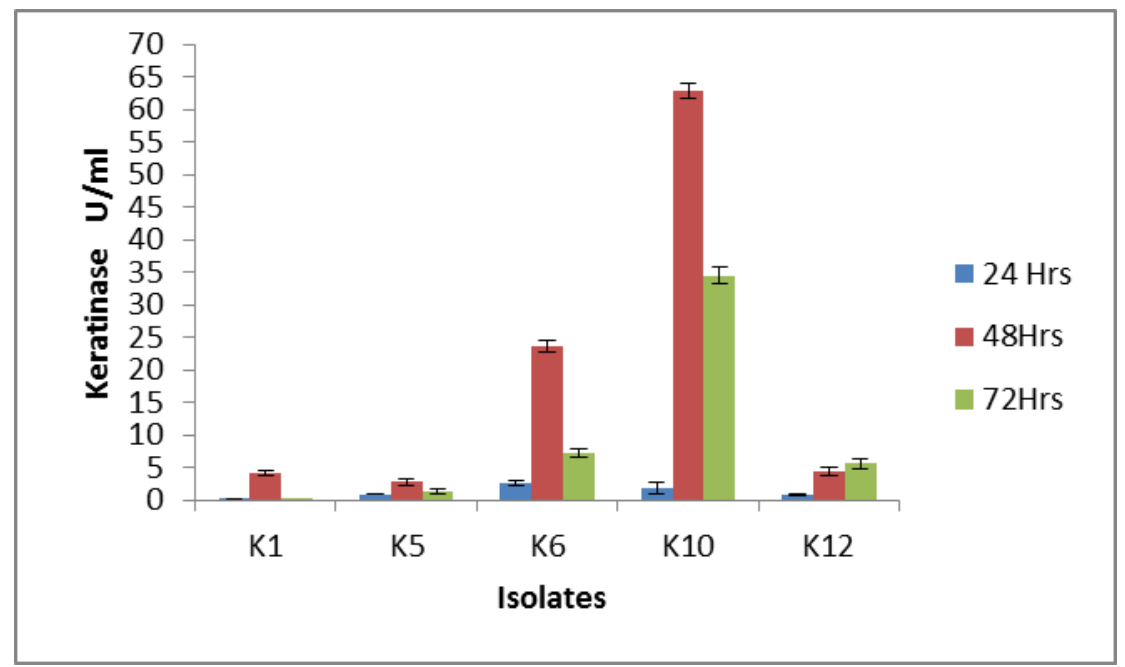

Fig.3 Effect of different co-carbon sources on keratinase production by Bacillus thuringiensis strain Bt407

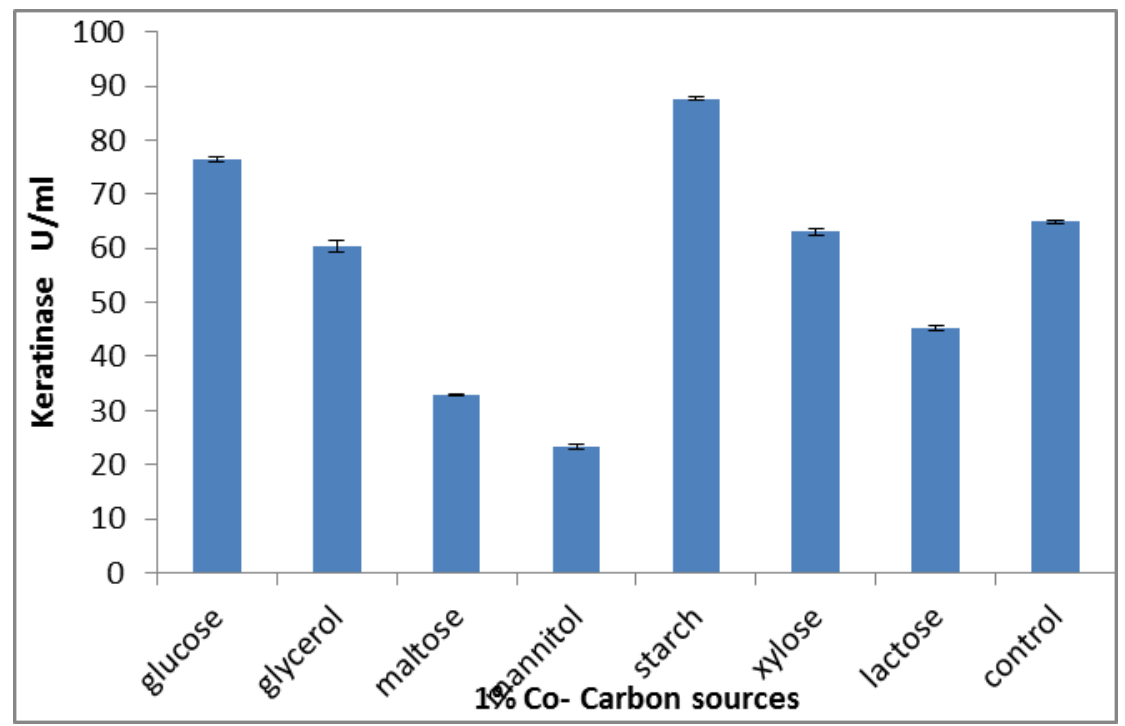


Fig.4 Effect of different co-nitrogen sources on keratinase production by Bacillus thuringiensis strain Bt407

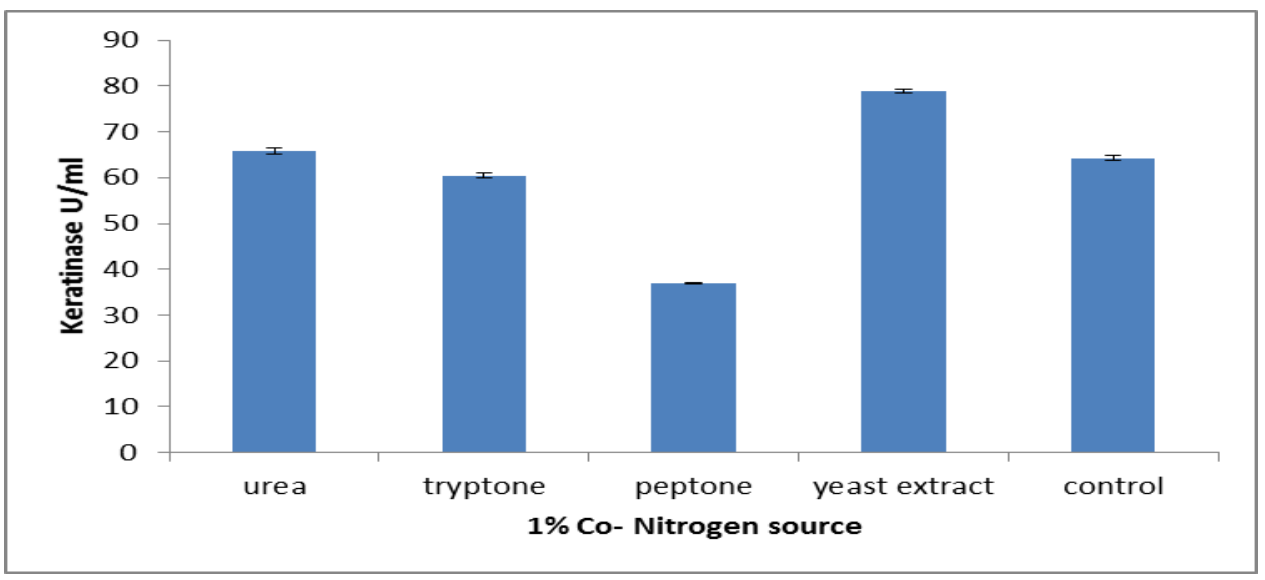

Fig.5 Effect of $\mathrm{MgSO}_{4}$ concentration on keratinase production by Bacillus thuringiensis strain Bt407

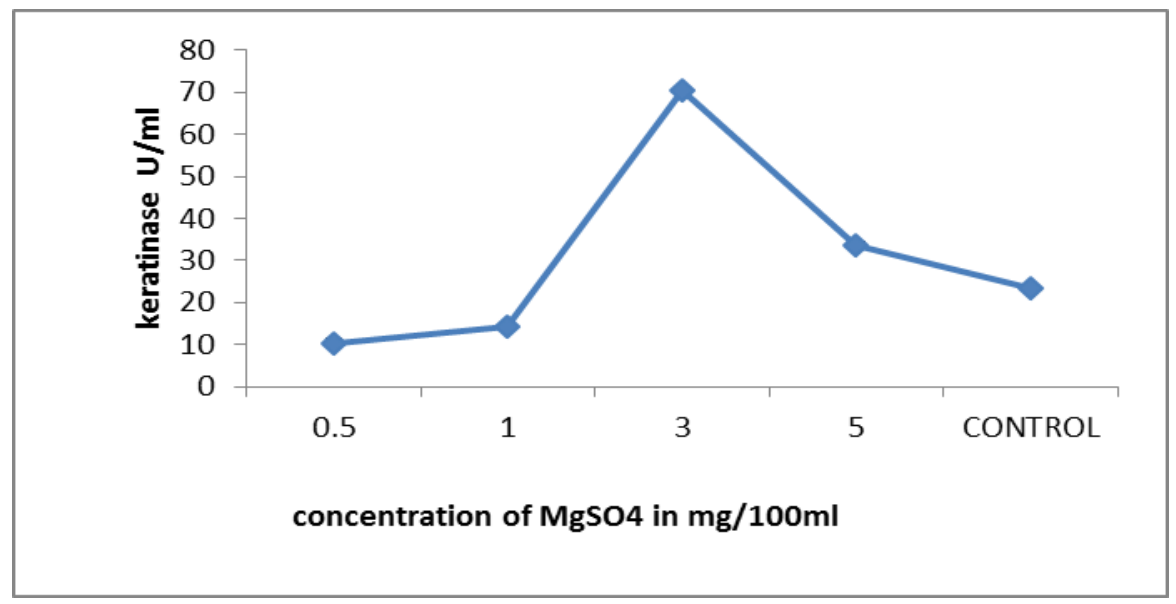

Fig.6 Effect of $\mathrm{CaCl}_{2}$ concentration on keratinase production by Bacillus thuringiensis strain Bt407

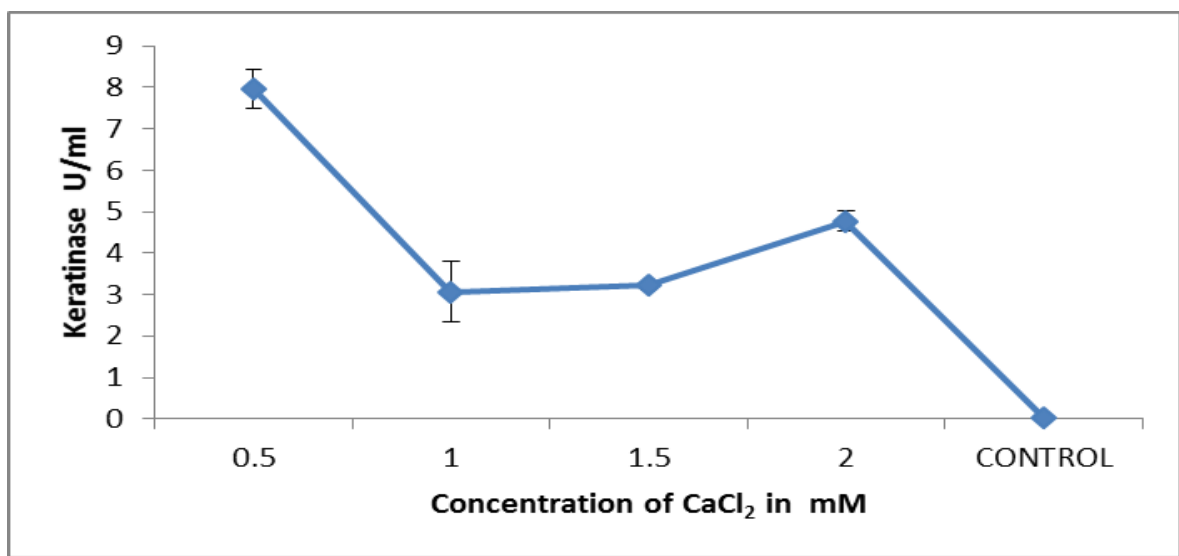


Fig.7 Effect of different $\mathrm{pH}$ values on keratinase production by Bacillus thuringiensis strain Bt407

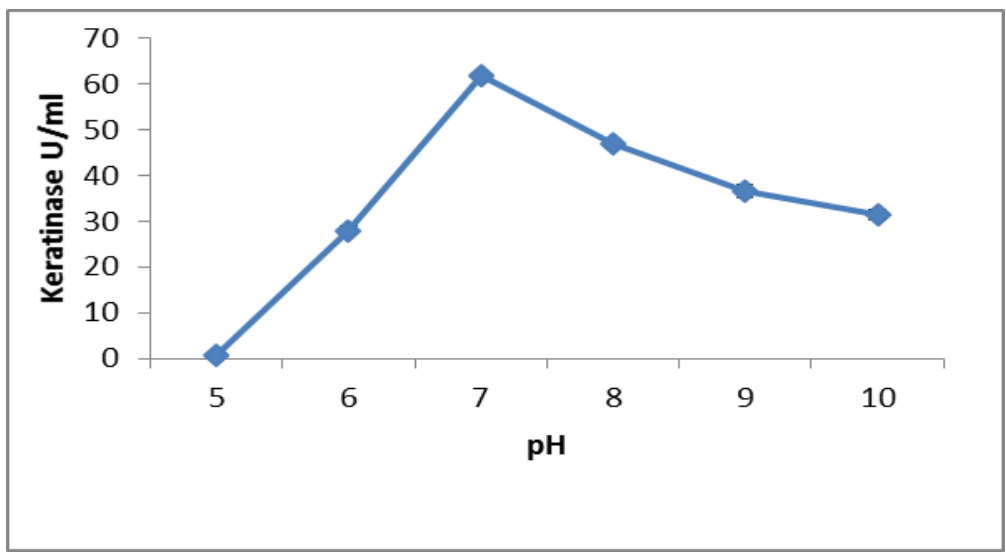

Fig.8 Effect of different temperatures on keratinase production by Bacillus thuringiensis strain Bt407

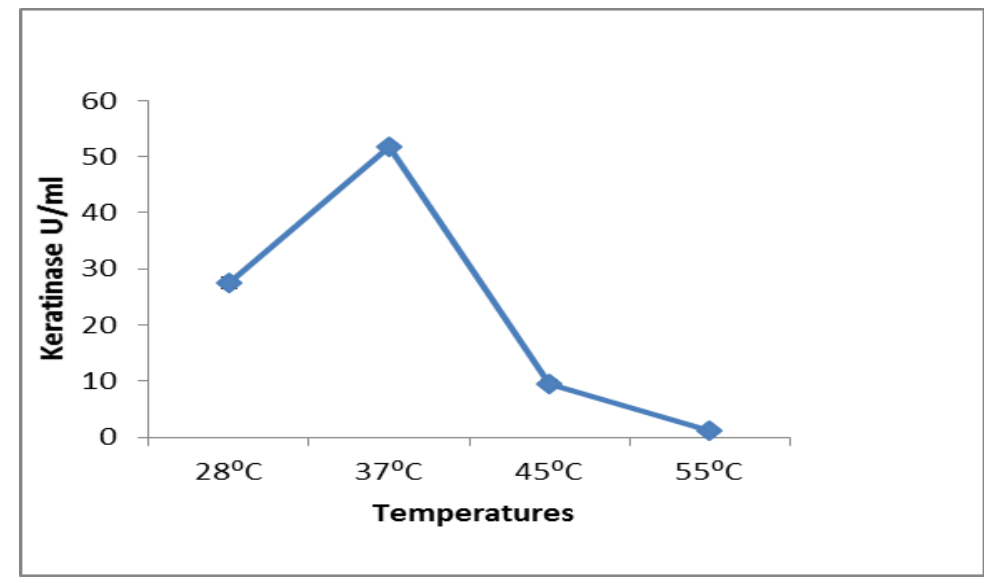

Fig.9 Effect of aeration on keratinase production by Bacillus thuringiensis strain Bt407

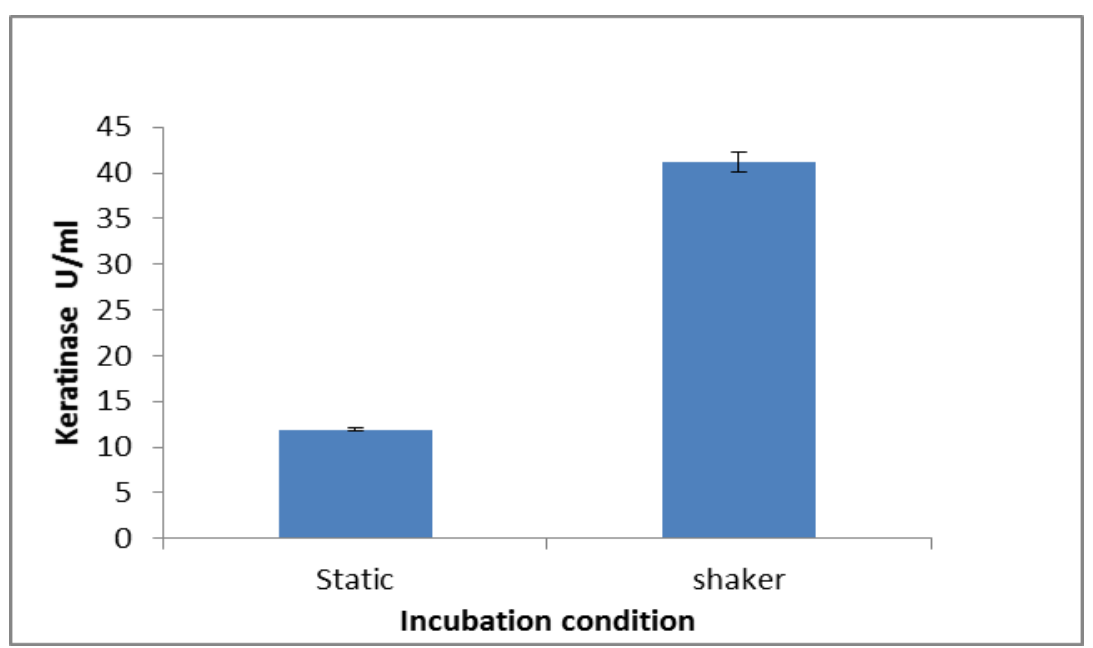


Fig.10 Utilization of Human hairs and human nails as substrates for keratinase production by Bacillus thuringiensis strain Bt407 at different incubation period

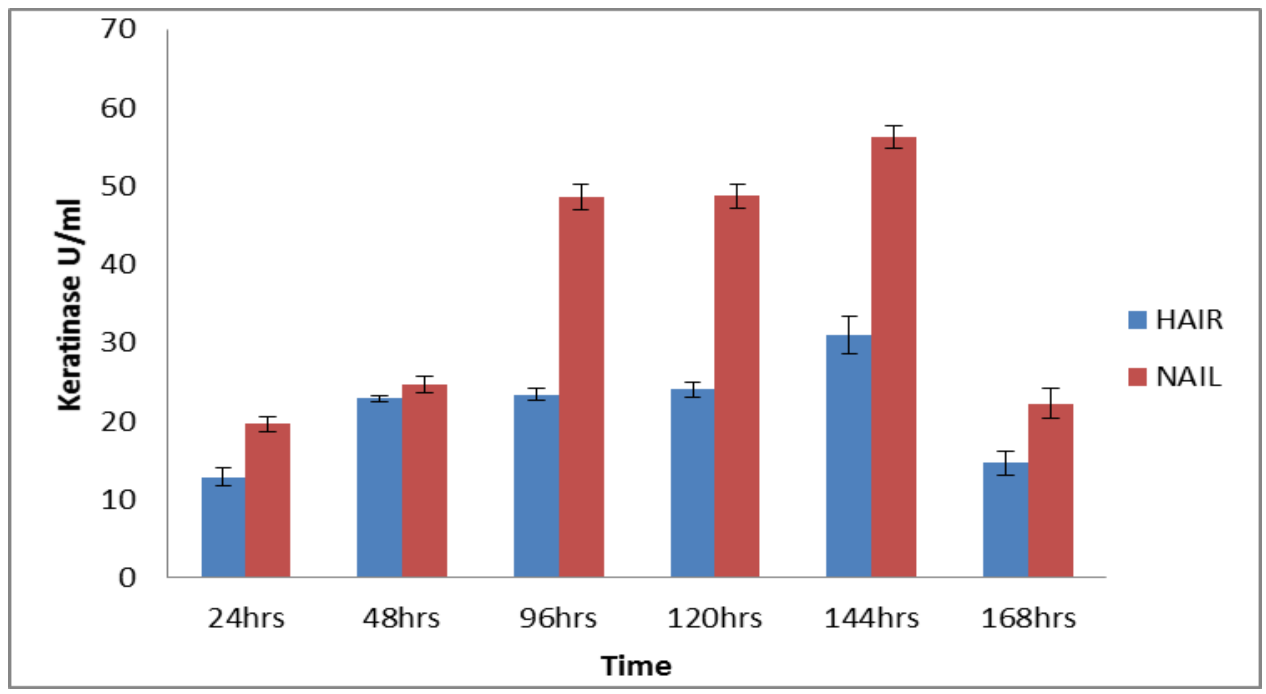

Fig.11 [A] SDS -PAGE of keratinase enzyme, [B] Zymogram, [C] Proteolytic activity of keratinase on casein agar plate
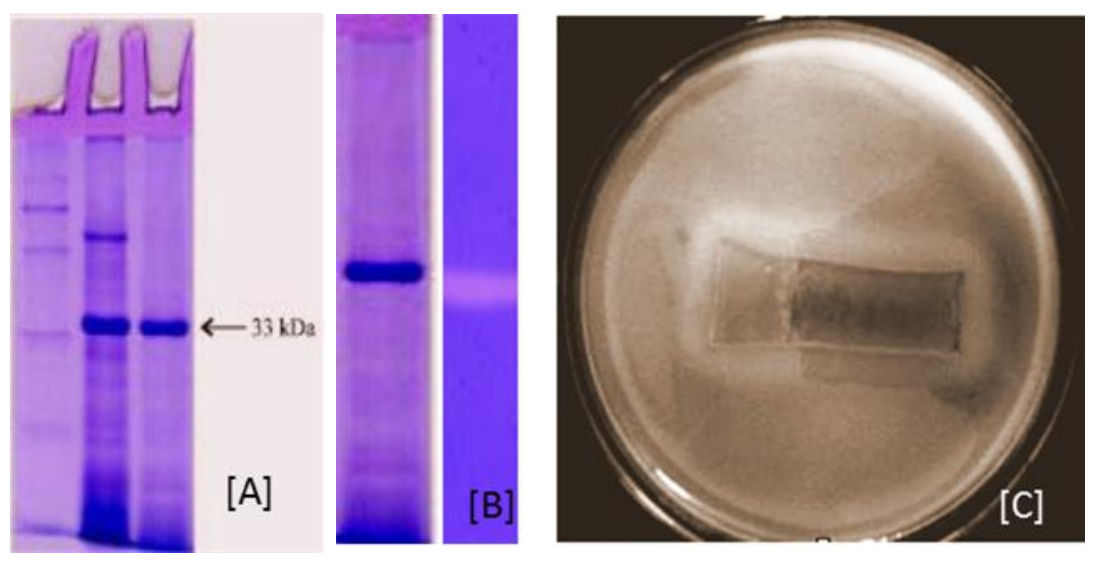

Fig.12 Effect of different $\mathrm{pH}$ values on enzyme activity

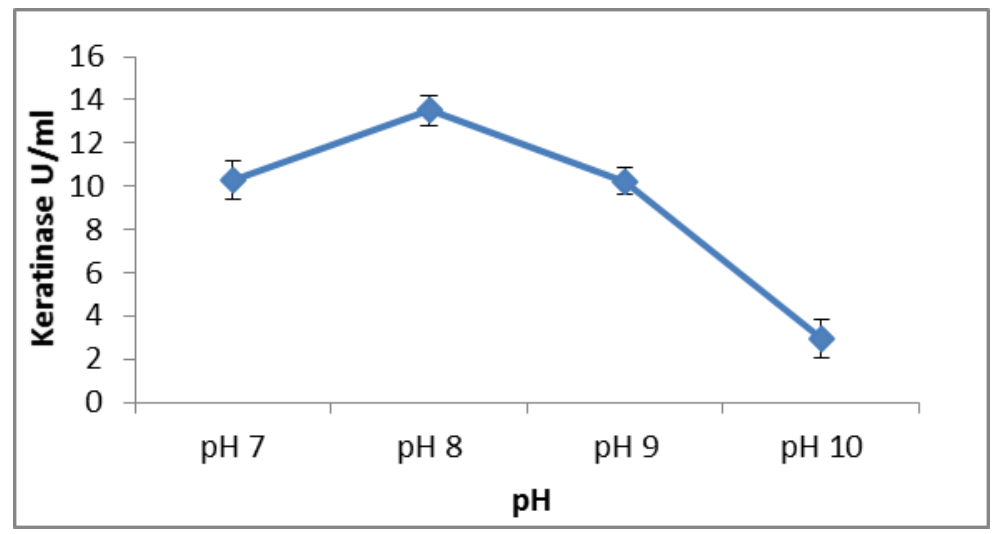


Fig.13 Effect of different temperatures on keratinase activity

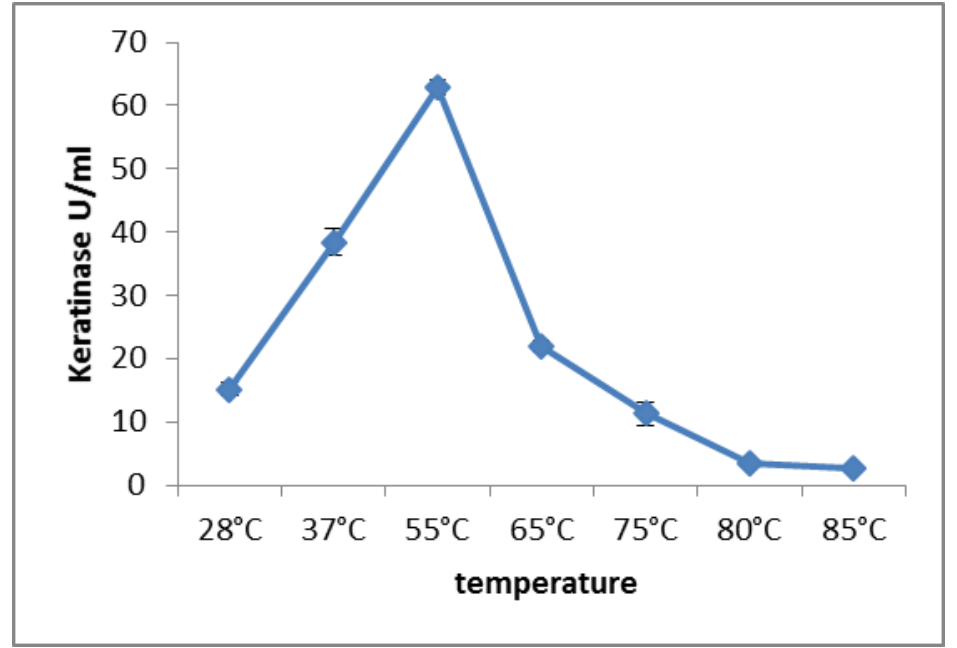

Fig.14 Effect of different metal ions on keratinase activity

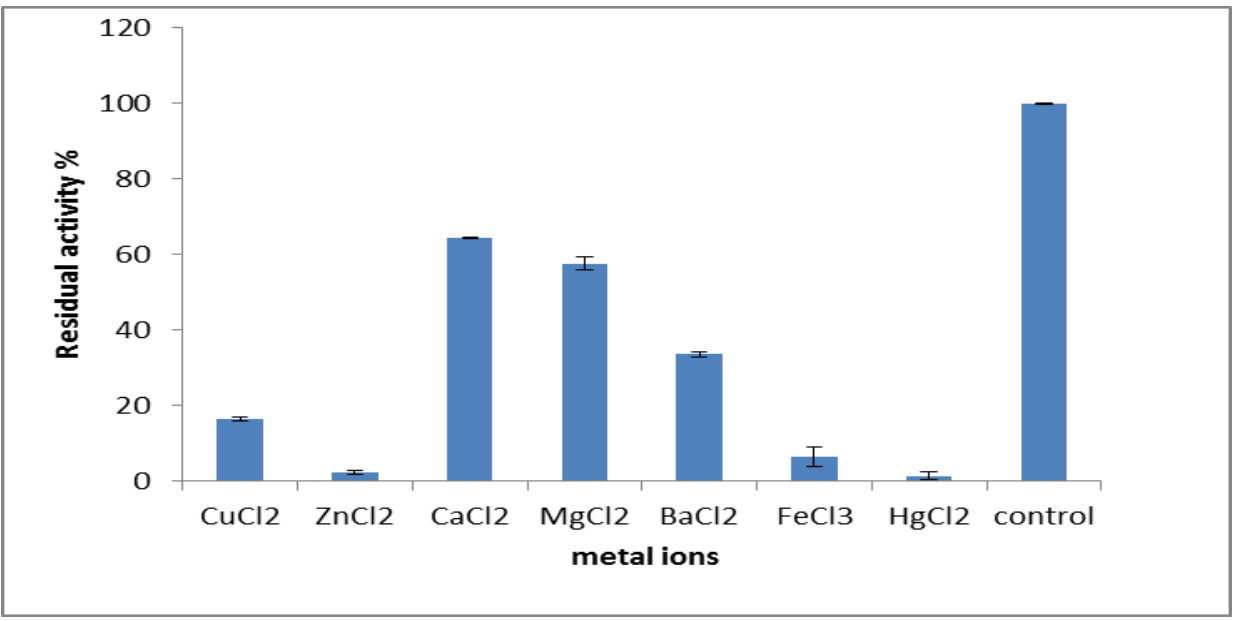

Fig.15 Effect of different inhibitors on keratinase activity

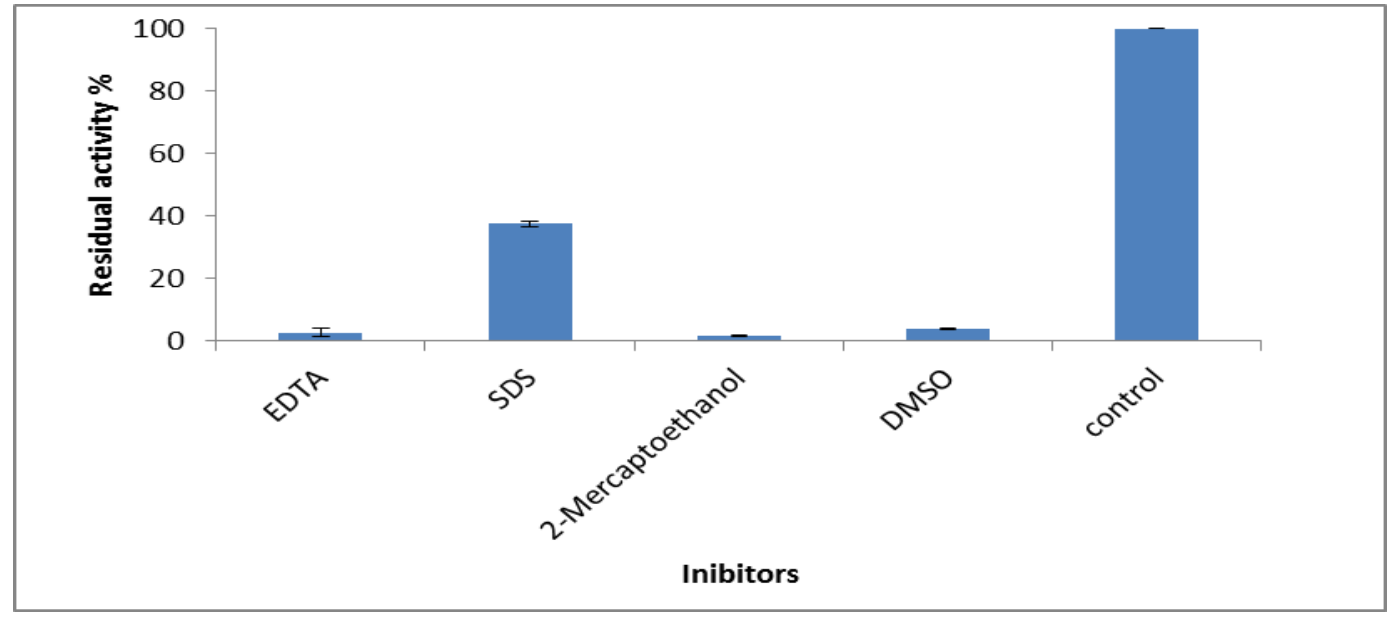


Fig.16 Effect of Keratinase on goat skin hair removal

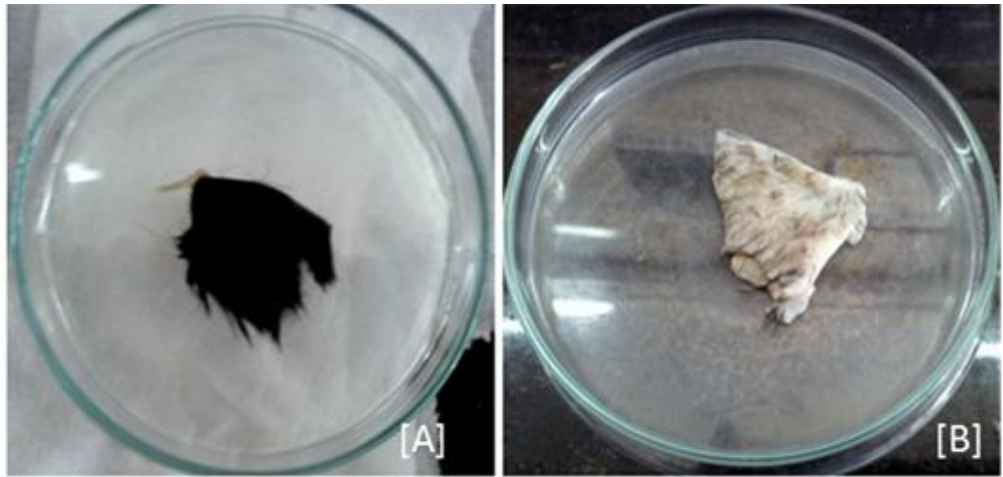

[A] Before addition of enzyme. [B] After addition of enzyme

Fig.17a [A] Control: Blood stain rinsed by Distilled Water. [B] Blood + Ariel: Blood stain rinsed in Ariel detergent solution. [C] Blood + Ariel + Enzyme: Blood stain rinsed by detergent followed by enzyme produced by Bacillus thuringiensis strain Bt407
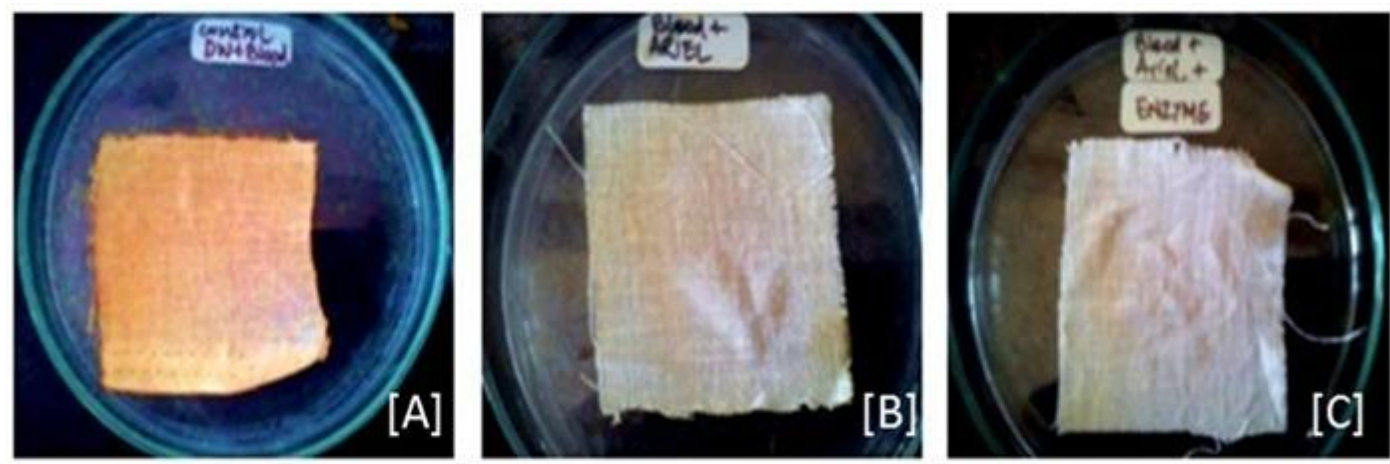

Fig.17b [A] Control: Egg yolk stain rinsed by Distilled Water. [B] Egg yolk stain + Ariel: Egg yolk stain rinsed in Ariel detergent solution. [C] Egg yolk stain + Ariel + Enzyme: Egg yolk stain rinsed by detergent followed by enzyme produced by the Bacillus thuringiensis strain Bt407
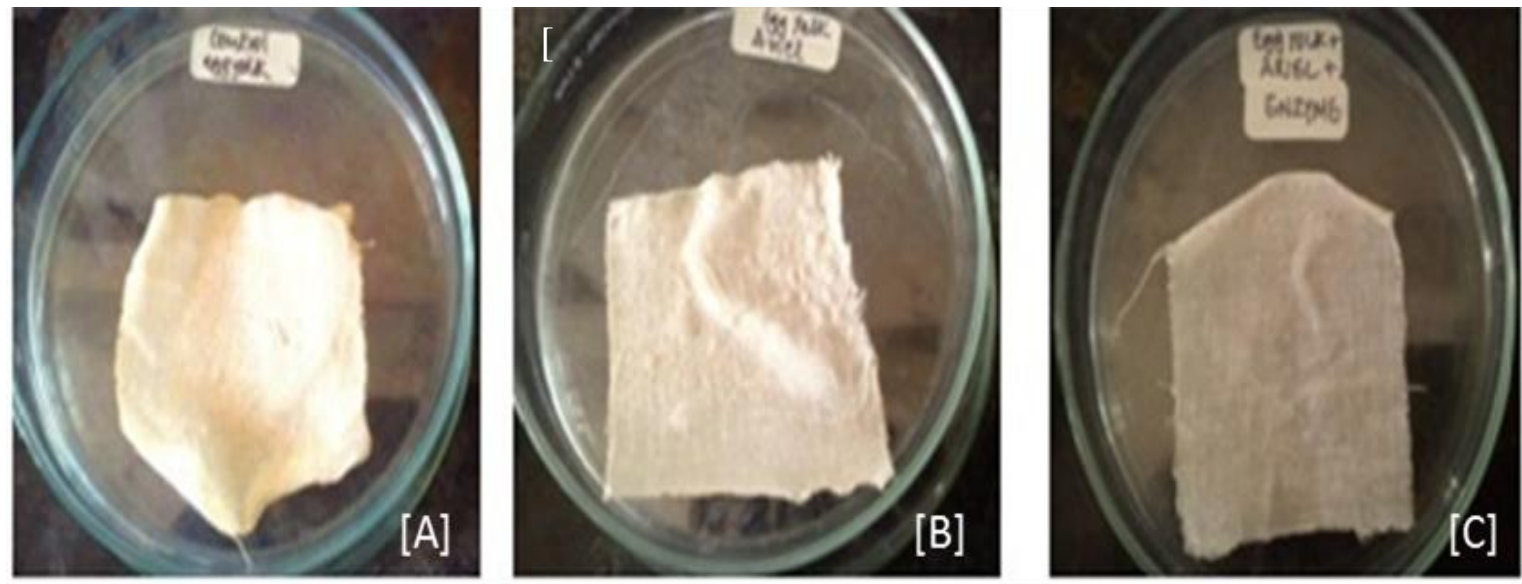
Table.1 Quantification of keratinase enzyme of different isolates at different Incubation time period

\begin{tabular}{|c|c|c|c|c|c|c|c|c|c|}
\hline \multirow[t]{2}{*}{ Isolate } & \multicolumn{3}{|c|}{$24 \mathrm{Hrs}$} & \multicolumn{3}{|c|}{$48 \mathrm{Hrs}$} & \multicolumn{3}{|c|}{ 72Hrs } \\
\hline & $\mathrm{U} / \mathrm{ml}$ & $\begin{array}{l}\mathrm{Mg} \\
\text { protein } \\
/ 100 \mathrm{ml}\end{array}$ & $\begin{array}{l}\text { Specific } \\
\text { activity } \\
\mathrm{U} / \mathrm{mg}\end{array}$ & $\mathrm{U} / \mathrm{ml}$ & $\begin{array}{l}\mathrm{Mg} \\
\text { protein } \\
/ 100 \mathrm{ml}\end{array}$ & $\begin{array}{l}\text { Specific } \\
\text { activity } \\
\mathrm{U} / \mathrm{mg}\end{array}$ & $\mathrm{U} / \mathrm{ml}$ & $\begin{array}{l}\mathrm{Mg} \\
\text { protein } \\
/ 100 \mathrm{ml}\end{array}$ & $\begin{array}{l}\text { Specific } \\
\text { activity } \\
\mathrm{U} / \mathrm{mg}\end{array}$ \\
\hline K1 & 0.22 & 12 & 0.001 & 4 & 9.62 & 0.41 & 0.023 & 80 & 0.0002 \\
\hline K5 & 0.89 & 30 & 0.029 & 2.5 & 16.5 & 0.151 & 1.34 & 67 & 0.002 \\
\hline K6 & 2.65 & 15 & 0.1766 & 23.68 & 14 & 1.68 & 7.24 & 34 & 0.212 \\
\hline K10 & 1.85 & 10 & 5.40 & 62.6 & 5.23 & 11.96 & 34.6 & 18.4 & 1.880 \\
\hline K12 & 0.72 & 16 & 0.045 & 4.5 & 28.2 & 0.160 & 5.6 & 12 & 0.466 \\
\hline
\end{tabular}

Table.2 Purification studies of keratinase enzyme produced by Bacillus thuringiensis strain Bt407

\begin{tabular}{|c|c|c|c|}
\hline Enzyme & Total protein content $(\mathbf{m g} / \mathbf{m l})$ & Enzyme U/ml & Specific activity U/mg \\
\hline Crude extract & 1.85 & 10 & 5.40 \\
\hline $\begin{array}{c}\text { Ammonium sulphate } \\
\text { precipitation }\end{array}$ & 3.26 & 23 & 8.67 \\
\hline After Dialysis & 5.45 & 62.62 & 11.96 \\
\hline
\end{tabular}

Table.3 Use of feather hydrolysate in microbiological medium

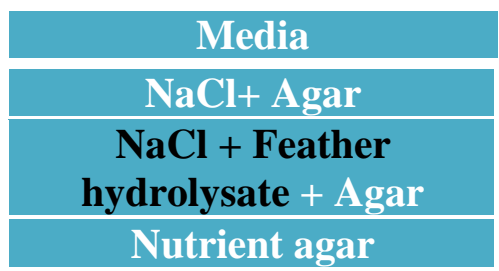

Key += Growth, - = no growth

However, B. subtilis AMR produced higher yield of enzyme in medium containing hairs (Mazotto et al., 2010), Bacillus subtilis KDN2 could not hydrolyze human hair (Cai and Zheng, 2009) and Bacillus licheniformis FK14 could neither hydrolyze human hairs nor human nails (Suntornsuk et al., 2005). Doratomyces microsporus was able to produce enzyme to hydrolyze native keratin such as stratum corneum, porcine nails and human nails. The human stratum corneum was seen to have a much higher degree of enzyme production than the rest of the substrates (Gradisar et al., 2000). A new Bacillus subtilis strain was able to hydrolyze sheep wool and human hair (Cai et al., 2008). Tichophyton mentagrophytes var. erinacei was able to degrade human hair and guinea pig hair (Muhsin and Aubaid, 2000).

\section{Purification Studies: Partial purification of Keratinase}

A cell-free extract of the isolate which was grown in optimized medium was precipitated using the Ammonium sulfate method. 
Following dialysis, an increase in the specific activity of the enzyme was observed (Table 2) Similar purification and dialysis technique was used to purify enzyme from Stenotrophomonas (Cao et al., 2009), Bacillus subtilis KD-N2 (Cai et al., 2008), Streptomyces minutiscleroticus DNA38 (Allure et al., 2015), Bacillus subtilis (Manju and Shanmugam, 2013), Streptomyces albus (Nayaka et al., 2013), Bacillus tequilensis strain Q7 (Jaouadi et al., 2015), Bacillus licheniformis FK-14 (Suntornsuk et al., 2005), B. thuringenesis SN2 (Agrahari and Wadhwa, 2010), Bacillus cereus MCM B-326 (Nilegaonkar et al., 2007) and Streptomyces minutiscleroticus DNA38 (Allure et al., 2015).

SDS- PAGE electrophoresis and Zymography

SDS-PAGE electrophoresis was carried out for the purified enzyme produced by Bacillus thuringiensis strain Bt407 and the molecular weight of the keratinase was found to be 33 $\mathrm{kDa}$. However, molecular weight of keratinase in $B$. thuringenesis $\mathrm{SN} 2$ is 120 $\mathrm{kDa}, 80 \mathrm{kDa}, 60 \mathrm{kDa}$ and $40 \mathrm{kDa}$ (Agrahari and Wadhwa, 2010). The molecular weight of major keratinases varies from 20 to $50 \mathrm{KDa}$ (Bockle et al., 1995). Likewise, it is similar to the keratinase MW of Bacillus pseudofirmus FA30-01 at $27 \mathrm{KDa}$ (Kojima et al., 2007). Similar results were obtained for Bacillus licheniformis keratinase (31.4 kDa) (Cheng et al., 1995), Bacillus licheniformis FK-14 (35 kDa) (Suntornsuk et al., 2005), Bacillus subtilis (30kDa) (Kazi et al., 2015), Bacillus pumilus (32 kDa) (Huang et al., 2003), Bacillus subtilis KD-N2 (30.5 kDa) (Cai et al., 2008), Bacillus (38kDa) (Peddu et al.,2009), Stenotrophomonas maltophilia (35.2 kDa) (Cao et al., 2009) and Streptomyces minutiscleroticus DNA 38 (29kDa) (Allure et al., 2015). However, there were studies which were showing molecular weight of keratinase lower or higher than molecular weight shown in our studies viz. Bacillus sp. JB 99 (66kDa) (Kainoor and Naik, 2010), Streptomyces albidoflavus (18 $\mathrm{kDa}$ (Bressollier et al., 1999), Fervidobacterum pennavorans $(130 \mathrm{kDa})$, (Friedrich et al., 1995), Bacillus sp. SCB3(134kDa) (Lee et al., 2002), B. cereus DCUW (80kDa) (Ghosh et al., 2008), Bacillus tequilensis strain Q7 (28.3 kDa) (Jaouadi et al., 2015), Bacillus subtilis (40kDa) (Manju and Shanmugam, 2013), Bacillus licheniformis strain HK-1 (46kDa) (Korkmaz and Dincer, 2004), Chrysosporium keratinophilum (69 kDa) (Dozie et al., 1994), Kocuria rosea (240kDa) (Bernal et al., 2006a) and Bacillus megaterium (41kDa) (Saibabu et al., 2013). Zymography analysis in SDS - PAGE showed a single band which corresponded keratinase activity was observed by clear zone of proteolytic activity in the zymogram (Fig. 11 A and B). Similarly the gel was placed on a Sterile Casein agar plates. A zone of clearence was observed around the gel on the plate indicating the proteolytic activity of the keratinase (Fig. 11C). Similar studies about zymography of keratinase is also done in case of Bacillus sp (Pandian et al., 2012), Bacillus sp. 50-3 (Zhang et al., 2009), Bacillus sp. P45 (Daroit et al., 2009), Bacillus cereus (Sousa et al., 2007), Bacillus subtilis AMR (Mazotto et al., 2010), Bacillius sp (Pandian et al., 2012), Bacillus tequilensis strain Q7 (Jaouadi et al., 2015), Acinetobacter sp. PD 12 (Shah, 2015), Streptomyces sp. strain 16(Xie et al., 2010), Lysobacter sp. A03 (Pereira et al., 2014), Brevibacillus brevis US575 (Jaouadi et al., 2013) and Onygena corvina (Huang et al., 2014).

Effect of different $\mathrm{pH}$ and temperature on keratinase enzyme activity

The maximum activity of keratinase of Bacillus thuringiensis strain $\mathrm{Bt} 407$ was 
observed at $\mathrm{pH} 8$ and $55^{\circ} \mathrm{C}$ indicating that the enzyme is alkaliphilic and active at high temperature (Fig. 12 and 13). These results are in accordance with Bacillus cereus DCUW and Chryseobacterium sp. kr6 (Ghosh et al., 2008; Riffel et al., 2007). But there is slight difference in optimum $\mathrm{pH}$ and temperature of keratinase activity of othere starins of Bacillus thuringiensis TS2 and $B$. thuringenesis $\mathrm{SN} 2$ where optimum $\mathrm{pH}$ was 10 and optimum temperature was $50^{\circ} \mathrm{C}$ (Sivakumar et al., 2012; Agrahari and Wadhwa, 2010). For many Bacillus species optimum $\mathrm{pH}$ and temperature for keratinase activity were studied and it was found that in case of Bacillus subtilis temperature $37^{\circ} \mathrm{C}$ and pH 10.0 (Kazi et al., 2015), for Bacillus subtilis AMR temperature $50^{\circ} \mathrm{C}$ and $\mathrm{pH} 9$ (Mazotto et al., 2010), for Bacillus sp. keratinase activity range was between $28^{\circ} \mathrm{C}$ $55^{\circ} \mathrm{C}$ and $\mathrm{pH}$ optima was 8.5 (Peddu et al.,2009), for Bacillus sp. JB 99 temperature $65^{\circ} \mathrm{C}$ and $\mathrm{pH} 10$ (Kainoor and Naik, 2010), for $B$. licheniformis strain $\mathrm{HK}-1$ temperature $60^{\circ} \mathrm{C}$ and $\mathrm{pH} 11.0$ (Korkmaz and Dinçer, 2004), for Bacillus sp. 50-3 temperature $60^{\circ} \mathrm{C}$ and pH 10.0 (Zhang et al., 2009), for Bacillus safensis LAU 13 temperature $40^{\circ} \mathrm{C}$ and $\mathrm{pH}$ 7.5 (Lateef et al., 2015), for Bacillus polymyxa $\mathrm{B} 20$ temperature $50^{\circ} \mathrm{C}$ and $\mathrm{pH} 10.2$ and for Bacillus cereus B5esz temperature $45^{\circ} \mathrm{C}$ and $\mathrm{pH} 7.4$ (Laba and Rodziewicz, 2010) was observed. For Streptomyces sclerotialus optimum temperature $55^{\circ} \mathrm{C}$ and $\mathrm{pH} 9.0$ was recorded (Yadav et al., 2011) and for Streptomyces albus optimum temperature and $\mathrm{pH}$ observed $40^{\circ} \mathrm{C}$ and 7.0 respectively (Nayaka et al., 2013).

\section{Effect of different metal ions on keratinase activity}

The effect of different metal ions on keratinase activity was studied. Metal ions like $\mathrm{Ca}^{+2}, \mathrm{Mg}^{+2}$, and $\mathrm{Ba}^{+2}$ were seen to enhance enzyme activity whereas $\mathrm{Cd}^{+2}, \mathrm{Cu}^{+2}$,
$\mathrm{Fe}^{+3}, \mathrm{Hg}^{+2}$ and $\mathrm{Zn}^{+2}$ were observed to inhibit keratinase activity from Bacillus thuringiensis strain Bt407 (Fig. 14). Similar results were reported in case of Bacillus thuringienesis SN2 (Agrahari and Wadhwa, 2010), Bacillus thuringiensis TS2 (Sivakumar et al., 2012), Bacillus sp. P7 (Correa et al., 2009), Bacillus megaterium (Saibabu et al., 2013), Bacillus sp. JB 99(Kainoor and Naik, 2010), Bacillus licheniformis strain HK-1 (Korkmaz and Dinçer, 2004), B. licheniformis YJ4 (Lin and Yin, 2010), Bacillus sp (Peddu et al.,2009), Bacillus subtilis MTCC 9102 (Balaji et al., 2008), B. pumilus CBS Bacillus species (Giongo et al., 2007), Brevibacillus brevis US575 (Jaouadi et al., 2013), Fervidobacterium islandicum AW-1 (Nam et al., 2002), Arthrobacter creatinolyticus KP015744 (Kate and Pethe, 2014), Bacillus sp. KG5 (Ahmetoglu et al., 2015).

However, in case of B. licheniformis FK 14, even $\mathrm{Zn}^{+2}$ in addition to $\mathrm{Ca}^{+2}, \mathrm{Mg}^{+2}$ and $\mathrm{Ba}^{+2}$ were seen to enhance keratinase activity (Suntornsuk et al., 2005) and keratinase from Bacillus safensis LAU 13 was activated by $\mathrm{Na}^{+}, \mathrm{Ca}^{+2}, \mathrm{Fe}^{+2}$ and $\mathrm{Mg}^{+2}$ but inhibited by $\mathrm{Mn}^{+2}$. A metal ion plays an important role for protease thermal stability as well (Bajorath et al., 1988). The effect of various metal ions on the production of a keratinase from Bacillus sp.SCB-3 was investigated and it was found out that the addition of $\mathrm{Zn}^{+2}, \mathrm{Cu}^{+2}, \mathrm{Co}^{+2}$ and $\mathrm{Hg}^{+2}$ resulted in decrease in the enzyme production of the enzyme. But the addition of $0.1 \mathrm{mM} \mathrm{Ca}^{+2}$ and $\mathrm{Mg}^{+2}$ gave an excellent production of enzyme suggesting that $\mathrm{Ca}^{+2}$ and $\mathrm{Mg}^{+2}$ maybe active ions in the native enzyme (Lee et al., 2002; Suntornsuk et al., 2005).

These results also suggest that $\mathrm{Ca}^{+2}$ ion is required for the enzyme activity or stability. The effect of $\mathrm{Ca}^{+2}$ on the enzyme under investigation may involve stabilization of the enzyme structure. 
Effect of different inhibitors on keratinase activity

Keratinase produced by Bacillus thuringiensis strain Bt407 was observed to retain its $37.67 \%$ residual activity in the presence of SDS while 2- mercaptoethanol, EDTA and DMSO were seen to inhibit the enzyme activity (Fig. 15). However, B. licheniformis strain HK-1 keratinolytic activity was partially inhibited by EDTA, 1, 10phenanthroline and PMSF and it was on the other hand increased by DMSO, TritonX-100 and SDS (Korkmaz and Dinçer, 2004). Other studies suggest that for Bacillus subtilis the keratinase activity was not inactivated in presence of EDTA (Kazi et al., 2015) but affected by $\mathrm{HgCl}_{2}$.

Use of feather hydrolysate as microbial feed in bacteriological media

Keratinase hydrolysed products were incorporated in the medium containing only salt and agar. Various laboratory cultures were grown on it at $37^{\circ} \mathrm{C}$ for $24 \mathrm{hrs}$ as shown in Table 3. It was seen that chicken feathers degraded by keratinase obtained from isolate can be used for preparation of economical microbial feed for growth of different microbiological cultures. Similar degraded chicken feathers obtained after treatment with keratinase from Streptomyces sp. IF 5 were used to prepare economical microbiological medium which supported growth of different microorganisms (Ramakrishnan et al., 2011).

\section{Dehairing capacity of keratinase on goat skin}

Alkaline Keratinases enables swelling of hair roots and subsequent attack of protease on hair follicle causing easy removal of hair. Bacillus thuringiensis strain Bt407 produced enzyme did not cause any damage to the skin but caused sucessful removal of hair from the goat skin after 24 hrs (Fig. 16). This means that the enzyme from this organism can be used as depilatory agent in tanning industry. Similar results were obtained Bacillus pumilus CBS Alkaline Proteinase (Jaouadi et al., 2009), Bacillus cereus MCM B-326 (Zambare et al., 2007) and Bacillus safensis LAU 13(Lateef et al., 2015). A few reports that indicate that keratinases could be useful depilating agents are available (Letourneau et al., 1998; Bressollier et al., 1999; Allpress et al., 2002; Friedrich and Kern, 2003). In fact, a keratinase from B. subtilis S14 (Macedo et al., 2005) was reported to completely eliminate the need for toxic sodium sulfide. Thus, sulfide-based "hair-destroying dehairing" processes that pose an environmental threat by increasing the BOD could be replaced by keratinase-based cleaner "hair-saving dehairing" technology. Brevibacillus brevis US575 (Jaouadi et al., 2013)

\section{Application of keratinase enzyme as detergent additive (Wash performance)}

Keratinase being a very sturdy enzyme is checked for its ability to act as a potent detergent additive which was determined by using a cotton cloth stained by Blood and egg yolk. Visual observations were made after subjecting the stained cloth pieces to various control and test solutions (Fig. 17a and 17b). The results indicate that the enzyme Keratinase was able to destain both blood and egg yolk stains on the cloth as shown in Figure $17 \mathrm{a}(\mathrm{C})$ and $17 \mathrm{~b}(\mathrm{C})$ compared to wash performance of the detergent Figure $17 \mathrm{a}(\mathrm{B})$ and $17 \mathrm{~b}(\mathrm{~B})$. Similar results were obtained for alkaline proteinase of Bacillus pumilus CBS (Jaouadi et al., 2009), Bacillus subtilis RM01(Rai et al., 2009), Bacillus megaterium (Saibabu et al., 2013), PaeniBacillus woosongensis TKB2 (Paul et al., 2014), Bacillus safensis LAU 13(Lateef et al., 2015) and Brevibacillus sp. strain AS-S10-II (Rai 
and Mukherjee, 2011; Gupta and Ramnani, 2006).

This study concludes that the optimization of production of keratinase from Bacillus thuringiensis Bt407 which was isolated from poultry site soil in a medium containing Feather meal (2\%), Yeast extract (1\%), Starch (1\%), $\quad \mathrm{MgSO}_{4} \quad 6 \mathrm{H}_{2} \mathrm{O} \quad(0.003 \%), \quad \mathrm{CaCl}_{2}$ $(0.5 \mathrm{mM}), \mathrm{KH}_{2} \mathrm{PO}_{4}(0.5 \%), \mathrm{K}_{2} \mathrm{HPO}_{4}(0.3 \%)$, $\mathrm{NaCl}(0.5 \%), \mathrm{pH} 7$, inoculated with $1 \% \mathrm{v} / \mathrm{v}$ pre-grown cell mass and incubated at $37^{\circ} \mathrm{C}$ on rotary shaker $(120 \mathrm{rpm})$ for 48 hours. Keratinase enzyme has optimum activity at $55^{\circ} \mathrm{C}$ and $\mathrm{pH} 8$ suggesting its thermophilic and alkaliphilic nature. Application of keratinase enzyme for depilatory action on goat skin, as a detergent additive and enzyme hydrolyzed feather meal in bacteriological medium as nitrogen source were also studied.

\section{References}

Adıgüzel Arife Candaş Zengin, Behzat Oral Bitlisli1, Niels Thomas Eriksen 2009.Potential Usage of Keratinolytic Enzymes from Bacillus cereus in the Leather Industry. Abstract from XXX Congress of the International Union of Leather Technologists \& Chemists Societies, Beijing, China.

Adinarayana Kunamneni, Ellaiah Poluri, and Siva Prasad Davuluri, 2003. Purification and partial characterization of thermostable serine alkaline protease from a newly isolated Bacillus subtilis PE-11, AAPS Pharm SciTech. 4(4): 440-448.

Agrahari S, Wadhwa N. 2010. Degradation of Chicken Feather a Poultry Waste Product by Keratinolytic Bacteria Isolated from Dumping Site at Ghazipur Poultry Processing Plant. International Journal of Poultry Science. 9(5):482-489.

Ahmetoglu N, Bekler FM, Acer O, Guven RG. 2015. Production, purification and characterisation of thermostable metalloprotease from newly isolated. EurAsian J Biosci.9, 1-11.

Akhtar, W. and Edwards H.G.M. 1997. Fouriertransform Raman spectroscopy of mammalian and avian keratotic biopolymers. SpectrochimActa. 53, 81-90.
Ali TH, Ali NH, Mohamed LA. 2011. Production, purification and some properties of extracellular keratinase from feathers-degradation by Aspergillus oryzae nrrl-447. 6(2):123-136.

Allpress JD, Mountain G, Gowland PC. 2002. Production, purification and characterization of an extracellular keratinase from Lysobacter NCIMB 9497. Letters in Applied Microbiology. 34:337-342.

Allure N, Madhusudhan DN, Agsar D. 2015. Detection of Keratinolytic Actinobacteria and evaluation of Bioprocess for Production of Alkaline Keratinase. Int.J.Curr.Microbiol.App.Sci.4(7): 907-918.

Anbu P, Gopinath SCB, Hilda a, Lakshmipriya T, Annadurai G. 2007. Optimization of extracellular keratinase production by poultry farm isolate Scopulariopsis brevicaulis. Bioresour Technol. 98(6):1298-1303. doi:10.1016/j.biortech.2006.05.047.

Anbu P, Hilda A, Sur H, Hur B, Jayanthi S. 2008. Extracellular keratinase from Trichophyton sp. HA-2 isolated from feather dumping soil. International Biodeterioration \& Biodegradation. $\quad 62, \quad 287-292$. doi:10.1016/j.ibiod.2007.07.017.

Anbu, P., Gopinath, S.C.B., Hilda, A., Lakshmipriya, T., Annadurai, G., 2005. Purification of keratinase from poultry farm isolate- Scopulariopsis brevicaulis and statistical optimization of enzyme activity. Enzyme Microb. Technol. 36, 639-647.

Anbu, P., Gopinath, S.C.B., Hilda, A., Lakshmipriya, T., Annadurai, G., 2007. Optimization of extracellular keratinase production by poultry farm isolate Scopulariopsis brevicaulis. Bioresour. Technol. 98, 1298-1303.

Azza M Abdel-fattah A. 2013. Novel keratinase from marine Nocardiopsis dassonvillei NRC2aza exhibiting remarkable hide dehairing. Egyptian Pharmaceutical Journal. 12,142-147 doi:10.4103/1687-4315.124016

Bajorath, J., Hinrichs, W. \& Saenger, W. 1988. The enzymatic activity of proteinase $\mathrm{K}$ is controlled by calcium. European Journal of Biochemistry. 176, 441-447.

Bakhtiar S, Estiveira RJ, Hatti-Kaul R. 2005. Substrate specificity of alkaline protease from alkaliphilic feather-degrading Nesterenkonia sp. AL20. Enzyme Microb Technol. 37(5):534-540. doi:10.1016/j.enzmictec.2005.04.003. 
Balaji S, Kumar MS, Karthikeyan R, Kumar R, Kirubanandan S, Sridhar R, Sehgal PK 2008. Purification and characterization of an extracellular keratinase from a hornmealdegrading Bacillus subtilis MTCC (9102). World J Microbiol Biotechnol. 24(11): 27412745

Balakumar S, Mahesh N, Arunkumar M, Sivakumar R, Hemambujavalli V. 2013. Optimization of Keratinase Production by Keratinolytic Organisms under Submerged Fermentation. International Journal of PharmTech Research. 5(3): 1294-1300.

Bernal, C., Cairo, J., Coello, N., 2006. Purification and characteriza- tion of a novel exocellular keratinase from Kocuria rosea. Enzyme Microb. Technol. 38, 49-54.

Bihari Z, Vidéki D, Mihalik E, Szvetnik A, Szabó Z. 2010.Degradation of Native Feathers by a Novel Keratinase-Producing, Thermophilic Isolate, Brevibacillus thermoruber T1E. Journal of Biosciences. 65(1-2): 134-140.

Błyskal B 2009. Fungi utilizing keratinous substrates. Int Biodeter Biodegr. 63, 631-653.

Bockel, S., Diamy, A. M. and Ricard, A. 1995. Optical diagnostics of active species in $\mathrm{N}-2$ microwave flowing postdischarges. Surface Coatings Technol. 74-5, 474-478.

Brandelli A, Riffel A. 2005. Production of an extracellular keratinase from Chryseobacterium sp. growing on raw feathers. Electronic Journal of Biotechnology. 8(1):35-42.

Bressollier P, Letourneau F, Urdaci M, Verneuil B. 1999. Purification and characterization of a keratinolytic serine proteinase from Streptomyces albidoflavus. Appl Environ Microbiol. 65(6):2570-2576.

Cai C, Chen J, Qi J, Yin Y, Zheng X. 2008. Purification and characterization of keratinase from a new Bacillus subtilis strain. J Zhejiang Univ Sci $\quad$ B. 9(9):713-720. doi:10.1631/jzus.B0820128.

Cai C, Lou B, Zheng X 2008. Keratinase production and keratin degradation by a mutant strain of Bacillus subtilis. J. Zhejiang Univ. Sci. 9(1):6067 doi:10.1631/jzus.B061620

Cai C, Zheng X. 2009. Medium optimization for keratinase production in hair substrate by a new Bacillus subtilis KD-N2 using response surface methodology. J Ind Microbiol Biotechnol. 36(7):875-883. doi:10.1007/s10295-009-05654.
Cao Zhang ZJ, Q, Wei DK, Chen L, WangJ, Zhang $\mathrm{XQ}$, et al., 2009. Characterization of a novel Stenotrophomonas isolate with high keratinase activity and purification of the enzyme. J Ind Microbiol Biotechnol.36, 181-8.

Cheng SW, Hu HM, Shen SW, Takagi H, Asano M, Tsai YC 1995. Production and characterization of a feather degrading Bacillus licheniformis PWD-1. Biosci. Biotechnol. Biochem. 59, 2239-2243.

Chou C. C, Lepore E, Antonaci P, Pugno N, 2015. Buehler MJ. Mechanics of trichocyte alphakeratin fibers: Experiment, theory, and simulation. J Mater Res. 30(1):26-35. doi:10.1557/jmr.2014.267.

Correa A.P.F., Daroit D.J., Brandelli A., 2010. "Characterization of a keratinase produced by Bacillus sp. P7 isolated from an Amazonian environment", International Biodeterioration \& Biodegradation, 64 (1): 1-6.

Cortezi M, Contiero J, Lima CJB De, 2008. Characterization of a Feather Degrading by Bacillus amyloliquefaciens Protease: A New Strain. World Journal of Agricultural Sciences. 4(5):648-656.

Daroit DJ, Corrêa APF, Brandelli A. 2009. Keratinolytic potential of a novel Bacillus sp. P45 isolated from the Amazon basin fish Piaractus mesopotamicus. Int Biodeterior Biodegradation. 63(3):358-363. doi:10.1016/j.ibiod.2008.11.008.

De Toni CH, Richter MF, Chagas JR, Henriques JAP and Termignoni C 2002. Purification and characterization of an alkaline serine endopeptidase from a feather-degrading Xanthomonas maltophila strain. Can J Microbiol. 48:342-348.

Deivasigamani B. and Alagappan K.M. 2008. Industrial application of keratinase and soluble proteins from feather keratins. J Environ Biol. 29, 933-936.

Dozie, I.N.S., Okeke, C.N. and Unaeze, N.C. 1994. A thermostable, alkaline-active, keratinolytic proteinase from Chrysosporium keratinophilum. World Journal of Microbiology and Biotechnology 10, 563-567.

Duarte TR, Oliveira SS, Macrae A, Cedrola SML, Mazotto AM, Souza EP, Melo ACN and Vermelho AB. 2011. Increased expression of keratinase and other peptidases by Candida parapsilosis mutants. Braz J Med Biol Res. 44, 212-216 
El-Gendy MM 2009. Keratinase production by endophytic Penicillium spp. Morsy1 under solid-state fermentation using rice straw. Appl Biochem Biotechnol. 162(3):780-794. doi:10.1007/s12010-009-8802-x.

El-Naghy MA, El-Ktatny MS, Fadl-Allah EM, Nazeer WW 1998. Degradation of chicken feathers by Chrysosporium georgiae. Mycopathologia. 143(2):77-84.

El-Refai $\mathrm{H}$ a., AbdelNaby $\mathrm{M}$ a., Gaballa a., ElAraby MH, Abdel Fattah a. 2005. Improvement of the newly isolated Bacillus pumilus FH9 keratinolytic activity. Process Biochem. 40(7):2325-2332. doi:10.1016/j.procbio.2004.09.006.

Fakhfakh-Zouari N, Hmidet N, Haddar A, Kanoun S, Nasri M 2010. A novel serine metallokeratinase from a newly isolated Bacillus pumilus A1 grown on chicken feather meal: biochemical and molecular characterization. Appl. Biochem. Biotechnol. 162, 329-344

Femi-Ola, T. O., Akinbobola, O. S. and Oluwaniyi, T. T 2015. Isolation and characterization of feather degrading bacteria from poultry soil. Agriculture and Biology Journal Of North America.146-154. doi:10.5251/abjna.2015.6.5.146.154.

Feughelman M 1985. Keratin. In: Kroschwitch JI (ed) Encyclopedia of polymer science and engineering, vol 8. Wiley, New York, pp 566600

Friedrich AB, Antranikian G, 1996. Keratin degradation by fervidobacterium pennavorans, a novel thermophilic anaerobic species of the order Thermotogales. Applied and Environmental Microbiology. 62(8):2875-2882.

Friedrich J, Kern S. 2003. Hydrolysis of native proteins by keratinolytic protease of Doratomyces microsporus. J Mol Catal B Enzym. 21(1-2):35-37. doi:10.1016/S13811177(02)00132-7.

Gassesse A, Kaul RH, Gashe BA and Mattiasson B 2003. Novel alkaline protease from alkalophilic bacteria grown on chicken feather. Enzyme Microbial Technol. 32, 519-24.

Ghosh A., Chakrabarti K., Chattopadhyay D. 2008. Degradation of raw feather by a novel high molecular weight extracellular protease from newly isolated Bacillus cereus DCUW, J. Ind. Microbiol. Biotechnol. 35 (8):825.

Giongo JL, Lucas FS, Casarin F, Heeb P, Brandelli A. 2007. Keratinolytic proteases of Bacillus species isolated from the Amazon basin showing remarkable dehairing activity. World J Microbiol Biotech. 23, 375-382.

Gioppo NMR, Moreira-Gasparin F, Costa AM, Alexanddrio AM, Souza CGM and Peralta RM 2009. Influence of the carbon and nitrogen sources on keratinase production $\mathbf{J}$ Ind Microbiol Biotechnol. 36,705-711.

Givskov, M.; Eberl, L. And Molin, S. 1991. Control of exoenzyme production, motility and cell differentiation in Serratia liquefaciens. FEMS Microbiology Letters. 148(2): 115-122.

Govarthanan M, Selvankumar T, Arunprakash S. 2011. Production of keratinolytic enzyme by a newly isolated feather degrading Bacillus Sp. from chick feather waste. International Journal of Pharma and Bio Sciences. 2(3):259-265.

Gradisar, H., Kern, S., Friedrich, J., 2000. Keratinase of Doratomyces microsporus. Applied Microbiology and Biotechnology. 53, 196-200.

Grazziotin A, Pimentel FA, de Jong EV, Brandelli A 2006. Nutritional improvement of feather protein by treatment with microbial keratinase. Anim Feed Sci Technol. 126, 135-144

Gupta R, Ramnani P. 2006. Microbial keratinases and their prospective applications: An overview. Appl Microbiol Biotechnol. 70(1):2133. doi:10.1007/s00253-005-0239-8.

Gupta S, Singh R. 2013. Statistical Modeling and optimization of keratinase production from newly isolated Bacillus subtilis. International Journal of Advanced Biotechnology and Research. 4(1):167-174.

Gupta S, Singh SP, Singh R. 2015. Synergistic effect of reductase and keratinase for facile synthesis of protein-coated gold nanoparticles. J Microbiol Biotechnol. 25(5):612-619.

Gurav, R.G Jingchun Tang, Jadhav, J. P. 2016. Biodegradation of keratinous waste by Chryseobacterium sp. RBT isolated from soil contaminated with poultry waste. J. Basic Microbiol. Biotech. 6:145. Doi: 10.1002/jobm.201100371.

Gushterova A, Vasileva-Tonkova E, Dimova E, Nedkov P, Haertlé T. 2005. Keratinase Production by Newly Isolated Antarctic Actinomycete Strains. World J Microbiol Biotechnol. 21(6-7):831-834. doi:10.1007/s 11274-004-2241-1.

Han Minghai. Wei Luo, Qiuya Gu and Xiaobin Yu 2012. Isolation and characterization of a keratinolytic protease from a feather-degrading 
bacterium Pseudomonas aeruginosa C11. African J Microbiol Res. 6(9):2211-2221. doi:10.5897/AJMR11.921.

Harde SM, Bajaj IB, Singhal RS. 2011. Optimization of fermentative production of keratinase from Bacillus Subtilis NCIM 2724 Agric. Food Anal. Bacteriol. 1(1): 54-65.

Huang Y, Busk PK, Lange L. 2015. Production and Characterization of Keratinolytic Proteases Produced by Onygena corvina. Fungal Genomics Biol. 4(1):119. doi:10.4172/21658056.1000119.

Ionata, E., Canganella, F., Bianconi, G., Benno, Y., Sakamoto, M., Capasso, A., Rossi, M., La Cara, F., 2008. A novel keratinase from Clostridium sporogenes bv. pennavorans bv. nov., a thermotolerant organism isolated from solfataric muds. Microbiol. Res. 163, 105- 112.

Ivana A. Cavello, Mariana Chesini, Roque A. Hours, and Sebastián F. Cavalitto 2013. Study of the Production of Alkaline Keratinases in Submerged Cultures as an Alternative for Solid Waste Treatment Generated in Leather Technology J. Microbiol. Biotechnol. 23(7): 1004-1014. http://dx.doi.org/10.4014/jmb. 1211.11016

Jain, R., Jain, P. C. And Agrawal, S. C. 2012. Feather degradation by Streptomyces exfoliatus CFS 1068. Annals of Microbiology. 62,973-978

Jaouadi NZ, Rekik H, Badis A, et al., 2013. Biochemical and Molecular Characterization of a Serine Keratinase from Brevibacillus brevis US575 with Promising Keratin-Biodegradation and Hide-Dehairing Activities. PLoS One. 8(10):1-18. doi:10.1371/journal.pone.0076722.

Jaouadi Zaraî N, Rekik H, Ben Elhoul M, et al., 2015. A novel keratinase from Bacillus tequilensis strain Q7 with promising potential for the leather bating process. Int $\mathrm{J}$ Biol Macromol.79, 952-964. doi:10.1016/j.ijbiomac. 2015.05.038.

Jayalakshmi T, Krishnamoorthy P, Ramesh G, Sivamani P. 2010. Isolation and Screening of a Feather-Degrading Keratinolytic Actinomycetes from Actinomyces sp. Journal of American Science. 6(12):45-48.

Jeong JH, Lee OM, Jeon YD, et al., 2010. Production of keratinolytic enzyme by a newly isolated feather-degrading Stenotrophomonas maltophilia that produces plant growthpromoting activity. Process Biochem. 45(10):1738-1745.

doi:10.1016/j.procbio.2010.07.020.
Jones LN, Simon M, Watts NR, Booy FP, Steven AC, Parry DAD 1997. Intermediate filament structure: hard a-keratin. Biophys Chem. 68:8393. doi:10.1016/S0301-4622(97)00013-6.

Kainoor PS, Naik GR. 2010. Production and characterization of feather degrading keratinase from Bacillus sp. JB 99. India J Biotechnol. 9(4):384-90.

Kansoh AL, Hossiny EN, El-hameed EKA. 2009. Keratinase production from feathers wastes using some local streptomyces isolates. Australian Journal of Basic and Applied Sciences. 3(2):561-571.

Kate S, Pethe A. 2014. Study of efficiency of Keratinase production by Arthrobacter creatinolyticus KP015744 isolated from leather sample International Journal of Advanced Research. 2(11):992-999.

Kaul S, Sumbali G 1997. Keratinolysis by poultry farm soil fungi. Mycopathologia. 139,137-140

Kazi YF, Kumar P, Soomro IH. 2013. Keratinolytic activity exhibited in an indigenous nondermatophytic fungus strain Cochliobolus lunatus isolated from Khairpur Sindh Pakistan. African Journal of Biotechnology. 12(14):16691674. doi:10.5897/AJB12.2820.

Kazi YF, Kumar P, Soomro IH. 2015. Characterization of the keratinolytic activity of indigenous Bacillus subtilis keratinase. Journal of Chemical and Pharmaceutical Research. 7(4):800-809.

Khardenavis A a, Kapley A, Purohit HJ. 2009. Processing of poultry feathers by alkaline keratin hydrolyzing enzyme from Serratia sp. HPC 1383. Waste Manag. 29(4):1409-1415. doi:10.1016/j.wasman.2008.10.009.

Kim J. 2007. Purification and Characterization of a Keratinase from a Feather-Degrading Fungus, Aspergillus flavus Strain K-03. Mycobiology. 35(4): 219-225.

Kim J., Lim W., Suh H. 2001. Feather-degrading Bacillus species from poultry waste. Process Biochem. 37(3):287-291. doi:10.1016/S00329592(01)00206-0.

Kojima M, Kanai M, Tominaga M, Kitazume S, Inoue A and Horikoshi K 2006. Isolation and characterization of a feather-degrading enzyme from Bacillus pseudofirmus FA30-01. Extremophiles. 10,229-235.

Korkmaz H, Hür H, Dincer S 2004. Characterization of alkaline keratinase of Bacillus licheniformis strain HK-1 from poultry waste. Annals of Microbiology. 54 (2): 201- 211. 
Kumar R, Balaji S, Uma TS, Mandal a B, Sehgal PK. 2010. Optimization of influential parameters for extracellular keratinase production by Bacillus subtilis (MTCC9102) in solid state fermentation using Horn meal-a biowaste management. Appl Biochem Biotechnol. 160(1):30-39. doi:10.1007/s12010008-8452-4.

Laba W, Choinska A, Rodziewicz A, Piegza M 2015. Keratinolytic abilities of Micrococcus luteus from poultry waste. Braz J Microbiol. 46(3):691-700. doi:10.1590/S1517-83824632 0140098 .

Laba W.and A. Rodziewicz, 2010. Keratinolytic potential of feather- degrading Bacillus polymyxa and Bacillus cereus. Polish Journal of Environmental Studies. 19(2): 371-378.

Laemmli U.K., 1970. Cleavage of structural proteins during the assembly of the head of bacteriophage T4, Nature. 227(5259): 680-685.

Lakshmi P. 2013. Open access Screening and Isolation of a Keratinase producing organism from soil samples of poultry waste. International Journal of Scientific \& Medical Research. 1(1): 13-18.

Lateef A, Adelere IA, Gueguim-Kana EB. 2015. Bacillus safensis LAU 13: A new source of keratinase and its multi-functional biocatalytic applications. Biotechnol Biotechnol Equip. 29(1):54-63. doi:10.1080/13102818.2014.986360.

Lateef, A., Oloke, J.K., Kana, E.B.G., Shobowale, B.O., Ajao, S.O. and Bello, B.Y. 2010. Keratinolytic activities of a new featherdegrading isolate of Bacillus cereus LAU08 isolated from Nigerian soil. Int. Biodeterior. Biodegrad. 64,162-165.

Lee H, Sub DB, Wang H, Shih JCH 2002. Characterization of a keratinolytic metalloprotease from Bacillus sp. SCB-3. Appl Biochem Biotechnol. 97, 123-133.

Letourneau F, Soussotte V, Bressollier P, Branland P, Verneuil B.1998. Keratinolytic activity of Streptomyces sp. S.K1-02: A new isolated strain. Lett Appl Microbiol. 26(1):77-80. doi:10.1046/j.1472-765X.1998.00281.x.

Lin H, Yin L. 2010. Feather meal and rice husk enhanced keratinases production by Bacillus licheniformis $\mathrm{Yj} 4$ and characters of produced keratinases. Journal of Marine Science and Technology.18 (3): 458-465.

Lin, X., J. C. H. Shih and H. E. Swaisgood 1996. Hydrolysis of feather keratin by immobilized keratinase. Appl. Environ. Microbiol. 62, 42734275.

Lin, X., Lee, C.G., Casale, E.S. \& Shih, J.C.H. 1992. Purification and characterization of a keratinase from a feather-degrading Bacillus licheniformis strain. Applied and Environmental Microbiology. 58, 3271-3275.

Lo WH, Too JR, Wu JY. 2012. Production of keratinolytic enzyme by an indigenous featherdegrading strain Bacillus cereus Wu2. J Biosci Bioeng. 114(6):640-647. doi:10.1016/j.jbiosc. 2012.07.014.

Longshaw CM, Wright JD, Farrell AM and Holland KT 2002. Kytococcus sedentarius, the organism associated with pitted keratolysis, produces two keratin degrading enzymes. J Appl Microbiol 93:810-816. doi:10.1046/j.1365-2672.2002. 01742.x.

Lowry OH, Rosenbrourgh NJ, Farr NJ and Randall JR 1951. Protein measurement with the Folin phenol reagent. J Biol Chem. 193, 265-75.

Lucas, F.S., Broennimann, O., Febbraro, I. and Heeb, P. 2003. High diversity among featherdegrading bacteria from a dry meadow soil. Microbial Ecology. 45, 282-290.

Mabrouk MEM. 2008. Feather degradation by a new keratinolytic Streptomyces sp. MS-2. World J Microbiol Biotechnol. 24(10):2331-2338. doi:10.1007/s11274-008-9748-9.

Macedo AJ, Beys Da Silva WO, Gava R, Driemeier D, Pêgas Henriques JA, Termignoni C. 2005. Novel keratinase from Bacillus subtilis S14 exhibiting remarkable dehairing capabilities. Appl Environ Microbiol. 71(1):594-596. doi:10.1128/AEM.71.1.594

Manju R. S.Shanmugam 2013. Isolation, Identification, Characterization of Bacillus Subtilis Subsp Subtilis., producing the keratinase enzyme under optimization method Indian Journal of applied research. 3(11): 421423.

Manoj Kumar, Kumar R, Malik DK. 2016. Keratin degradation by bacterial strain isolated from poultry farm soil. Journal of Pharmacy Research. 10(2):113-115.

Marchisio Filipelo V 2000. Keratinophilic fungi: their role in nature and degradation of keratinic substrates.In: Kushwaha RKS, Guarro J (eds) Biology of dermatophytes and other keratinophilic fungi. Revista Iberoamericana de Micologia, Bilbao, pp 86-92.

Mazotto AM, Lage Cedrola SM, Lins U, et al., 2010. Keratinolytic activity of Bacillus subtilis 
AMR using human hair. Lett Appl Microbiol. 50(1):89-96. doi:10.1111/j.1472-765X.2009. 02760.x.

Mehta RS, Jholapara RJ, Sawant CS. 2014. Isolation of A Novel Feather-Degrading Bacterium and Optimization of It's of Its Cultural Conditions for Enzyme Production. International Journal of Pharmacy and Pharmaceutical Sciences. 6(1):194-201.

Mitsuiki S, Ichikawa M, Oka T, Sakai M, Moriyama Y, Sameshima Y, Goto M, Furukawa K. 2004. Molecular characterization of a keratinolytic enzyme from an alkaliphilic Nocardiopsis sp. TOA-1. Enzyme Microb Technol. 34, 482-489.

Mitsuiki S, Ichikawa M, Okab T, Sakai M, Moriyamac Y, Sameshimab Y, Goto M and Furukawa M 2004. Molecular characterization of a keratinolytic enzyme from an alkaliphilic Nocardiopsis sp. TOA-1. Enz Microb Tech. 34,482-489.

Moallaei, H., Zaini, F., Larcher, G., Beucher, B. and Bouchara, J. P. 2006. Partial purification and characterization of a $37 \mathrm{kDa}$ extracellular proteinase from Trichophyton vanbreuseghemii. Mycopathologia. 161, 369-375.

More SS, Sridhar DL, Prakash SN, Vishwakarma J, Umashankar S. 2013. Purification and properties of a novel fungal alkaline keratinase from Cunninghamella echinulata. Turkish Journal of Biochemistry-Turk $\mathrm{J}$ Biochem. 38(1):68-74. doi:10.5505/tjb.2013.37928.

Mousavi S, Salouti M, Shapoury R, Heidari Z. 2013. Optimization of keratinase production for feather degradation by Bacillus subtilis. Jundishapur J Microbiol. 6(8):6-10. doi:10.5812/jjm. 7160 .

Muhsin TM, Aubaid a H. 2000. Partial purification and some biochemical characteristics of exocellular keratinase from Trichophyton mentagrophytes var. erinacei. Mycopathologia. 150(3):121-125. http://www.ncbi.nlm.nih.gov/ pubmed/11469759.

Mukhopadhyay, R. P. \& Chandra, A. L. 1990. Kerati- nase of a Streptomycete. Indian. J. Exp. Biol. 28, 575-577.

Nam G.W, D.W. Lee, H.S. Lee, N.J. Lee, B.C. Kim, E.A. Choe, J.K. Hwang, M.T. Suhartono, R. Pyun, 2002.Native feather degradation by Fervidobacterium islandicum AW-1, a newly isolated keratinase-producing thermophilic anaerobe, Arch. Microbiol. 178, 538 - 547.

Nayaka S, Gireesh B K, Vidyasagar GM. 2013. Purification and characterization of keratinase from native feather- degrading Streptomyces albus International Journal of Development Research. 3(8):034-039.

Nilegaonkar SS, Zambare VP, Kanekar PP, Dhakephalkar PK, Sarnaik SS. 2007. Production and partial characterization of dehairing protease from Bacillus cereus MCM B-326. Bioresour Technol. 98(6):1238-1245. doi:10.1016/j.biortech.2006.05.003.

Ningthoujam DS and Kshetri P 2010. A thermostable alkaline protease from a moderately halo- alkalithermotolerant Bacillus subtilis strain SH1. Austra J Basic Appl Sci. 4(10): 5126-5134.

Onifade a. a., Al-Sane N a., Al-Musallam a. a., AlZarban S. 1998. A review: Potentials for biotechnological applications of keratindegrading microorganisms and their enzymes for nutritional improvement of feathers and other keratins as livestock feed resources. Bioresour Technol. 66(1):1-11. doi:10.1016/ S0960-8524(98)00033-9.

Pandian S, Sundaram J, Panchatcharam P. 2012. Isolation, identification and characterization of feather degrading bacteria. European Journal of Experimental Biology. 2 (1):274-282.

Park G-T, Son H-J. 2009. Keratinolytic activity of Bacillus megaterium F7-1, a feather-degrading mesophilic bacterium. Microbiol Res. 164(4):478-485. doi:10.1016/j.micres.2007.02.004.

Pathak AP, Deshmukh KB. 2012. Alkaline protease production, extraction and characterization from alkaliphilic Bacillus licheniformis KBDL4: a Lonar soda lake isolate. Indian J Exp Biol. 50(8):569-576. http://www.ncbi.nlm.nih.gov/ pubmed/23016494.

Pathange Prakash. Jayalakshmi SK, Sreeramulu K. 2009. Production of keratinase by free and immobilized cells of Bacillus halodurans strain PPKS-2: partial characterization and its application in feather degradation and dehairing of the goat skin. Appl Biochem Biotechnol. 160(7):1909-1920. doi:10.1007/s12010-0098702-0.

Patience N, Abigail O, Ponchang W, Deborah A, 2015. Keratinolytic activity of Cladosporium and Trichoderma species isolated from barbers' landfill. International Journal of Biosciences. 6(10): 104-115.

Paul, T., Das, A., Mandal, A., Halder, S.K., Das Mohapatra, P.K. et al., 2014. Biochemical and structural characterization of a detergent stable 
alkaline serine keratinase from PaeniBacillus woosongensis TKB2: potential additive for laundry detergent. Waste Biomass Valorization. 5(4):563-574.

Peddu J, Chitturi C, Lakshmi V. 2009. Purification and Characterization of Keratinase from Feather Degrading Bacillus sp. The Internet Journal of Microbiology. 8(2):1-7.

Pereira JQ, Lopes FC, Petry MV, Medina LF da C, Brandelli A. 2014. Isolation of three novel Antarctic psychrotolerant feather-degrading bacteria and partial purification of keratinolytic enzyme from Lysobacter sp. A03. Int Biodeterior Biodegrad.88:1-7. doi:10.1016/ j.ibiod.2013.11.012.

Pillai, P and Archana G 2008. Hide depilation and feather disintegration studies with keratinolytic serine protease from a novel Bacillus subtilis isolate. Appl Microbiol Biotechnol. 78, 643-50.

Pissuwan D, Suntornsuk W. Production of Keratinase by Bacillus sp. FK 28 Isolated in Thailand. 2001. Department of Microbiology, King Mongkut's University of Technology Thonburi, Bangkok 10140, Thailand

Prakash P, Jayalakshmi SK, Sreeramulu K 2010. Purification and characterization of extreme alkaline, thermostable keratinase, and keratin disulfide reductase produced by Bacillus halodurans PPKS-2. Appl Microbiol Biotechnol. 87, 625-633

Preethi K, Anand M, Thazeem B. 2015. Isolation and Identification of Keratinolytic Bacteria from Tannery Effluent: A Study on Their Biodegradative and Dehairing Activity. International Journal of Multidisciplinary Research and Development. 2(10):227-234.

Rai SK, Konwarh R, Mukherjee AK. 2009. Purification, characterization and biotechnological application of an alkaline $\beta$ keratinase produced by Bacillus subtilis RM-01 in solid-state fermentation using chicken-feather as substrate. Biochem Eng J. 45(3):218-225. doi:10.1016/j.bej.2009.04.001.

Rai, S.K. \& Mukherjee, A.K. 2011. Optimization of production of an oxidant and detergent-stable alkaline $\beta$-keratinase from Brevibacillus sp. strain AS-S10-II: Application of enzyme in laundry detergent formulations and in leather industry. Biochemical Engineering Journal. 54(1): 47-56

Ramakrishnan J, Balakrishnan H, Raja STK, Natarajan S, Renganathan S, Radha VN. 2011. Formulation of economical microbial feed using degraded chicken feathers by a novel Streptomyces sp: Mitigation of environmental pollution. Brazilian J Microbiol. 42(3):825-834.

Ramnani P, Gupta R. 2004. Optimization of medium composition for keratinase production on feather by Bacillus licheniformis RG1 using statistical methods involving response surface methodology. Biotechnol Appl Biochem. 40(Pt2):191-196. doi:10.1042/BA20030228.

Ramnani P, Singh R, Gupta R 2005. Keratinolytic potential of Bacillus licheniformis RG1: structural and biochemical mechanism of feather degradation. Can J Microbiol. 51(3):191-196.

Ramya, K., Deepak, V. M. M. and Anju Tankachi 2014. Isolation, Optimization Of Production Conditions, Characterisation And Partial Purification Of Keratinase Enzyme From Bacillus Sp. International Journal of Current Research. 6 (01): 4413-4419.

Rayudu K, Jayaraj YM, Ravi M, Anjum S. 2013. Ratinolytic protease production from keratinaceous wastes. J Recent Adv Appl Sci. 28, 69-72.

Rayudu Krishna, Y M Jayaraj RM and KSSA. 2011. Isolation, Identification and Characterization of A Novel Feather- Degrading Bacillus Species Ker 17 Strain. Asian J Biochem Pharm Res. 1(4):74-83.

Riffel A, Brandelli A. 2006. Keratinolytic bacteria isolated from feather waste. 2006 Brazilian Journal of Microbiology. 37, 395-399.

Riffel A, Lucas F, Heeb P, Brandelli A. 2003. Characterization of a new keratinolytic bacterium that completely degrades native feather keratin. Arch Microbiol. 179(4):258265. doi:10.1007/s00203-003-0525-8.

Rissen S and Antranikian G 2001. Isolation of Thermoanaerobacter keratinophilus sp. nov., a novel thermophilic, anaerobic bacterium with keratinolytic activity. Extremophiles. 5, 399408

Sahoo DK, Halder SK, Das A, Jana A, Paul T, Thatoi H. 2015. Keratinase production by Bacillus weihenstephanensis PKD5 in solidstate fermentation and its milk clotting potential. Indian Journal of Biotechnology. 14,200-207.

Saibabu V, Niyonzima FN, More SS. 2013. Isolation, Partial purification and Characterization of Keratinase from Bacillus megaterium. International Research Journal of Biological Sciences. 2(2):13-20. 
Sangali, S. and Brandelli, A. 2000. Feather keratin hydrolysis by a Vibrio sp. kr2 strain. Journal of Applied Microbiology. 89, 735-743

Schrooyen, P.M.M., Dijkstra, P.J., Oberthur, R.C., Bantjes, A., Feijen, J., 2001. Partially carboxymethylated feather keratins 2 . Thermal and mechanical properties of films. Journal of Agricultural and Food Chemistry. 49, 221-230.

Selvam K, Vishnupriya B. 2012. Biochemical and Molecular Characterization of Microbial Keratinase and Its Remarkable Applications. International Journal of Pharmaceutical \& Biological Archives. 3(2):267-275.

Shah M. 2015. A novel feather degrading Acinetobacter sp. PD 12 isolated from feather waste dumping site in Mumbai Introduction: European Academic Research; III(1):757-773.

Shankar T, Thangamathi P, Sathiya C, Sivakumar T. 2014. Statistical optimization of keratinase production by Bacillus thuringiensis. Journal of Global Biosciences. 3(2):477-483.

Sharaf EF, Khalil NM. 2011. Keratinolytic activity of purified alkaline keratinase produced by Scopulariopsis brevicaulis (Sacc.) and its amino acids profile. Saudi J Biol Sci. 18(2): 117-121. doi:10.1016/j.sjbs.2010.12.011.

Silveira ST, Casarin F, Gemelli S and Brandelli A 2010. Thermodynamics and kinetics of heat inactivation of a novel keratinase from Chryseobacterium sp. Strain kr6. Appl Microbiol Biotechnol. 162, 548-560.

Singh CJ. 1999. Exocellular proteases of Malbranchea gypsea and their role in keratin deterioration.Mycopathologia. 143(3):147-150.

Sivakumar T, Shankar T, Vijayabaskar P, Ramasubramanian V. 2012. Optimization for Keratinase Enzyme Production Using Bacillus thuringiensis TS2. Academic Journal of Plant Sciences. 5(3): 102-109. doi:10.5829/idosi.ajps.2012.5.3.6279.

Son HJ, Park HC, Kim HS, Lee CY 2008. Nutritional regulation of keratinolytic activity in Bacillus pumilis. Biotechnol Lett. 30, 461-465.

Sousa, F., Jus, S., Erbel, A., Kokol, V., CavacoPaulo, A. and Gubitz, G.M. 2007. A novel metalloprotease from Bacillus cereus for protein fibre processing. Enzyme Microb Technol. 40, 1772-1781.

Steinert, P.M., 1993. Structure, function, and dynamics of keratin intermediate filaments. J. Invest. Dermatol. 100, 729-734.
Suntornsuk W, Suntornsuk L. 2003. Feather degradation by Bacillus sp. FK 46 in submerged cultivation. Bioresour Technol. 86(3):239-243.

Suntornsuk W, Tongjun J, Onnim P, et al., 2005. Purification and Characterisation of Keratinase from a Thermotolerant Feather-degrading Bacterium. World J Microbiol Biotechnol. 21(67):1111-1117. doi:10.1007/s11274-005-0078-x.

Syed DG, Lee JC, Li WJ, Kim CJ, Agasar D. 2009. Production, characterization and application of keratinase from Streptomyces gulbargensis. Bioresour Technol. 100(5):1868-1871. doi:10.1016/j.biortech.2008.09.047.

Szabo I, Benedek A, Szabo IM and Barabas G 2000. Feather degradation with a thermotolerant Streptomyces graminofaciens strain. World J Microbiol Biotechnol. 16, 253-5.

Talebi M, Emtiazi G, Akhavan Sepahy A, Zaghian S. 2013. Zymogram analysis of alkaline keratinase produced by nitrogen fixing Bacillus pumilus ZED17 exhibiting multiprotease enzyme activities. Jundishapur J Microbiol. 6(10):1-6. doi:10.5812/jjm.7974.

Tapia, D.M.T., Simoes, M.L.G., 2008. Production and partial characterization of keratinase produced by a microorganism isolated from poultry processing plant wastewater. African Journal of Biotechnology. 7, 296-300.

Tatineni R, Doddapaneni KK, Potumarthi RC, et al., 2008. Purification and characterization of an alkaline keratinase from Streptomyces sp. Bioresour Technol. 99(6): 1596-1602. doi:10.1016/j.biortech.2007.04.019.

Thys RCS, Lucas FS, Riffel A, Heeb P, Brandelli A. 2004. Characterization of a protease of a feather-degrading Microbacterium species. Lett Appl Microbiol. 39(2):181-186. doi:10.1111/j.1472-765X.2004.01558.x.

Tork S, Aly MM, Nawar L, Arabia S. 2010. Biochemical and Molecular Characterization of a New Local Keratinase Producing Pseudomomanas sp., MS21. Asian Journal of Biotechnology. 2(1):1-13.

Vermelho AB, Mazotto AM, de Melo ACN, et al., 2009. Identification of a Candida parapsilosis strain producing extracellular serine peptidase with keratinolytic activity. Mycopathologia. 169(1):57-65. doi:10.1007/s11046-009-9231-7.

Vermelho AB. 2011. Biodegradation of feather waste by extracellular keratinases and gelatinases from Bacillus spp. World J. Microbiol. Biotechnol. 27, 1355-1365. 
Veselá M, Friedrich J. 2009. Amino acid and soluble protein cocktail from waste keratin hydrolysed by a fungal keratinase of Paecilomyces marquandii. Biotechnol Bioprocess Eng. 14(1):84-90. doi:10.1007/s12257-008-0083-7.

Vidhya D, Palaniswamy M. 2013. Identification and characterization of a local bacterial strain. IJPBS. 3(3):308-316

Voet, D., Voet, J.G. 1995. In: Biochemistry, (Ed. Stiefel, J.) 2nd edn. Wiley, New York, pp.154156.

Wang J-J, Shih JCH. 1999. Fermentation production of keratinase from Bacillus licheniformis PWD1 and a recombinant B. subtilis FDB-29. J Ind Microbiol Biotechnol. 22(6):608-616. doi:10.1038/sj.jim.2900667.

Xie F, Chao Y, Yang X, et al., 2010. Bioresource Technology Purification and characterization of four keratinases produced by Streptomyces sp. strain 16 in native human foot skin medium. Bioresour Technol. 101(1):344-350. doi:10.1016/j.biortech.2009.08.026

Xu B., Zhong Q., Tang X., Yang Y. and Huang Z., 2009. Isolation and characterization of a new keratinolytic bacterium that exhibits significant feather-degrading capability, Afr. J. Biotechnol. 8(18): 4590-4596.

Yadav A.K., S Vardhan, M.S Yandigeri, A.K. Srivastava and D.K. Arora 2011. Optimization of keratin degrading enzyme from thermoplilic strain of Streptomyces sclerotialus. 6: 693- 705.

Yamamura S, Morita Y, Hasan Q, Yokoyama K and Tamiya E. 2002. Keratin degradation: a cooperative action of two enzymes from Stenotrophomonas sp., Biochem. Biophys. Res. Commun., 294, 1138-1143.

Zambare VP, Nilegaonkar SS, Kanekar PP. 2007. Production of an alkaline protease by Bacillus cereus MCM B-326 and its application as a dehairing agent. World J Microbiol Biotechnol. 23(11):1569-1574. doi:10.1007/s11274-0079402-y.

Zhang, B., Sun, Z., Jiang, D-D., Niu, T-G., 2009. Isolation and purification of alkaline keratinase from Bacillus sp. 50-3. African Journal of Biotechnology. 8, 2598-2603

Zhou X, Idler WW, Stevent AC, Roopii DR, Steinerts PM. 1988. The Complete Sequence of the Human Intermediate Filament Chain Keratin10. J Biol Chem. 263(30):15584-15589.

\section{How to cite this article:}

Victoria Uttangi and Aruna, K. 2018. Optimization of Production and Partial Characterization of Keratinase Produced by Bacillus thuringiensis strain Bt407 Isolated from Poultry Soil. Int.J.Curr.Microbiol.App.Sci. 7(04): 596-626. doi: https://doi.org/10.20546/ijcmas.2018.704.069 